\title{
El Qhapaqñan en el Alto Loa, norte de Chile: Un estudio micro y macromorfológico ${ }^{1}$
}

\author{
José Berenguer R. ${ }^{2}$, Iván Cáceres R. ${ }^{3}$, Ceecilia Sanhueza T. ${ }^{4}$ y Pedro Hernández V. ${ }^{5}$
}

\section{RESUMEN}

Se entregan los resultados de una prospección pedestre y de cobertura total de $125 \mathrm{~km}$ de camino inca en el Alto Loa, entre las localidades de Miño por el norte y Lasana por el sur $\left(21^{\circ} 39^{\prime}-22^{\circ} 20^{\prime}\right.$ Lat. S). Se describen: 1) el derrotero y características constructivas del camino inca con relación a la topografía y el tipo de superficie del terreno por el que atraviesa; 2) los sitios con recintos y los marcadores camineros localizados a su vera; 3) sus conexiones con evidencias viales anteriores, contemporáneas y posteriores, y 4) su relación con el arte rupestre. Se discuten estos resultados en conexión con problemas de la prehistoria regional y se evalúa críticamente la idea de que el camino inca del Alto Loa es un eslabón del llamado "camino real de la costa".

Palabras claves: camino inca - Desierto de Atacama prospección - vialidades.

\section{ABSTRACT}

This paper gives the results of a $125 \mathrm{~km}$-long full-coverage survey of the Inca road, carried out on foot in the Upper Loa river basin, between the locations of Miño, to the north, and Lasana, to the south $\left(21^{\circ} 39^{\prime}-22^{\circ} 20^{\prime}\right.$ Lat. S). We describe: 1) the building characteristics and course of the road in relation to the topography and nature of the terrain it goes across; 2) the road markers and sites with enclosures they are associated to; 3) relationships with evidences of earlier, contemporary and later roads; and 4) the relationships with rock art sites. We discuss these results in connection with questions about the regional prehistory, and we critically evaluate the notion that the Upper Loa's Inca road is a segment of the so-called "Royal Road of the Coast".

Key words: Inca road-Atacama Desert - surface survey - road network.

Recibido: marzo 2004. Manuscrito revisado aceptado: marzo 2005.

1 Esta investigación es resultado del Proyecto FONDECYT 1010327, "Arqueología del sistema vial de los incas en el Alto Loa, II Región".

2 Museo Chileno de Arte Precolombino, Casilla 3687, Santiago, CHILE. Email: jberenguer@museoprecolombino.cl

3 Casilla 234, Correo de Paine, Santiago, CHILE. Email: icaceres@unete.com

\section{Introducción}

Casi al final de su libro The Inca road system, Hyslop (1984: 335, 337, 339) enfatiza la necesidad de completar el estudio de diferentes trayectos del Qhapaqñan a lo largo de los Andes, con la finalidad de agregar nuevas piezas al gigantesco rompecabezas y contribuir a la elaboración de síntesis regionales. En particular, singulariza el área entre Atico (Perú) y el río Loa (Chile) como una de las nueve áreas prioritarias en los Andes que requieren ser investigadas. $\mathrm{Y}$ en efecto, incluso 20 años después de la monografía del investigador estadounidense, se sabe muy poco acerca del camino occidental que cruzaba longitudinalmente este territorio, diversamente referido en la literatura como "camino costero", "camino de los llanos" o "camino real de la costa" (Garcilaso de la Vega 1995 [1604]).

En el presente artículo contribuimos a esta tarea colectiva, investigando el árido y escasamente poblado valle superior del río Loa, más conocido como Alto Loa (II Región de Antofagasta, norte de Chile). ${ }^{6}$ Los motivos por los cuales nos concentramos en este valle se explican en la siguiente sección y las razones por las cuales asociamos esta área al "camino occidental" se discuten críticamente al final del artículo. Se describen y analizan el trazado del camino entre Miño por el norte ( $21^{\circ} 39^{\prime}$ Lat. S) y Lasana por el sur $\left(22^{\circ} 20^{\prime}\right.$ Lat. S), los nueve tramos que componen este trayecto y los principales elementos que lo integran. Abordamos el estudio desde un enfoque particularista o micromorfológico, dirigido a re-

4 Museo Chileno de Arte Precolombino, Casilla 3687, Santiago, CHILE. Email: csanhueza@hotmail.com

5 Arquitecto Gonzalo Mardones 1185, Depto. 406, Santiago, CHILE. Email: pedrohernandez@metacontrol.cl

6 Una primera versión de este trabajo fue presentada en el simposio dirigido por Roberto Bárcena y Rubén Stehberg, "Tawantinsuyu 2003: Recientes avances en arqueología y etnohistoria", en el $51^{\circ}$ Congreso Internacional de Americanistas, Santiago, 14-18 de julio, 2003. 
gistrar elementos específicos de la construcción de la vía que sean de potencial o manifiesto significado cultural, como también holístico o macromorfológico, orientado a registrar información acerca de la extensión, conectividad y configuración global del sistema vial (Trombold 1991: 4-5). Nuestra aproximación es, por lo tanto, esencialmente arqueológica y, por ahora, fundamentalmente descriptiva, aunque al final de artículo nos permitimos avanzar algunas interpretaciones tendientes a problematizar en función de los resultados de la investigación.

\section{Antecedentes}

En el norte de Chile las publicaciones no reportan hasta ahora caminos incas longitudinales en el desierto central y tampoco en el litoral o borde costero. En cambio, segmentos de la arteria han sido parcialmente descritos por algunos autores en las tierras altas de la Región de Tarapacá (p.e., Santoro 1982; Núñez 1965). En la Región de Antofagasta, en tanto, se ha recorrido y documentado gran parte de los más de $400 \mathrm{~km}$ de camino incaico que, a través del así llamado "Despoblado de Atacama", unía al oasis de San Pedro de Atacama con el valle de Copiapó (Iribarren y Bergholz 1972; Niemeyer y Rivera 1983; Hyslop 1984; Hyslop y Rivera 1984). El camino que pasaba por la cuenca alta del río Salado ha sido recientemente objeto de investigaciones enfocadas tanto a reconstruir su derrotero (Varela 1999) como a reflexionar sobre su dimensión ceremonial a través de la oralidad de los habitantes locales (Castro y Varela 2000). Sin embargo, resta todavía investigar el curso superior del río Loa o Valle del Alto Loa, un corredor ubicado en el cuadrante noreste de la Región de Antofagasta, que enlaza a los oasis de la antigua Atacama con los valles y el altiplano tarapaqueños, en Chile, así como con el Altiplano Meridional de Bolivia.

Investigar la ruta incaica del Alto Loa es importante por varios motivos. Al sumarse a investigaciones ya desarrolladas por otros estudiosos o aún en curso en la Región de Antofagasta, el estudio de esta ruta sentaría las bases para una primera síntesis regional sobre el trazado de la red vial de los incas en tierras atacameñas. Además, contribuiría eventualmente a incrementar el espectro de formas de construcción vial conocidas y a entender mejor la relación de este sistema de caminos con las condiciones ambientales, especialmente en medios con una aridez no tan severa como el "Despoblado de Atacama", pero más acentuada que la cuenca alta del río Salado y que la Región de Tarapacá. Permitiría también incrementar el número de sitios incaicos o locales relacionados con los incas en el valle, enriqueciendo la renovada problemática sobre este período en la región. Asimismo, podría aportar materiales más "puros" o menos mezclados que en zonas más complejas y densamente pobladas, como es el caso de las cuencas del río Salado y del salar de Atacama; como señala Hyslop (1984: 339; Nielsen 1997 Ms), los caminos que ofrecen mejores perspectivas para la recolección de grandes cantidades de información arqueológica inca son, generalmente, las arterias importantes que pasan por áreas aisladas y desoladas, donde la conservación arqueológica es excelente y los componentes incaicos son más evidentes, debido a que las influencias culturales locales son mínimas. Y éste es, sin duda, el caso del Alto Loa. Ayudaría, por otro lado, a revelar una parte importante de la red caminera y logística que hizo factible la explotación por los incas del recientemente descubierto Complejo Minero San José del Abra (Núñez 1999; Salazar 2002). Posibilitaría, finalmente, discutir no sólo las conexiones del camino con los asentamientos incaicos registrados en el valle durante el pasado decenio (Castro 1992; Berenguer 1994, 2004a), sino también abrir debate acerca del rol de Lasana durante el Período Tardío, ya que las escasas evidencias incaicas registradas allí hasta el momento (Rydén 1944; Pollard 1970) pueden no estar haciendo justicia a la verdadera magnitud de la ocupación cuzqueña en esa localidad.

Referencias al Alto Loa como una ruta incaica se encuentran en unas pocas y heterogéneas fuentes. Diversos mapas generales que intentan reconstruir la red de caminos incas a través de todos los Andes, publicados por Regal (1936), Levillier (1942), von Hagen (1955) y Strube (1963) bosquejan un trazado del camino longitudinal occidental en que la vía parece internarse oblicuamente desde la Región de Tarapacá por el Alto Loa en dirección noroeste-sureste, para dirigirse aparentemente a la cuenca alta del río Salado o directamente a San Pedro de Atacama. En su mapa de los trayectos de caminos incas que prospectó a través de los Andes, así como en el mapa general del sistema vial que adjunta en su publicación, Hyslop (1984: 4, Fig. 1.1) repite este trazado esquemático, ajustándose a las propuestas de Levillier (1942) y von Hagen 
(1955). Es obvio que la pequeña escala de estos mapas y el largo tiempo que ha pasado desde su publicación, excusa a sus autores de muchos reparos que, desde perspectivas locales o regionales y a partir de datos más recientes, pueden hacérseles por sus imprecisiones. El problema es que tienden a difundir y perpetuar gruesos errores, a veces ante grandes audiencias. Por ejemplo, tan recientemente como en 2002, un artículo de divulgación científica en una revista que ha hecho de la cartografía uno de sus principales valores, incluye un mapa de la red vial inca en los Andes que reitera uno de estos trazados. ${ }^{7}$ Por eso, quisiéramos hacer notar que en todos estos mapas el camino figura atravesando diagonalmente las dos grandes cadenas montañosas que escoltan el valle del Alto Loa, lo que no se ajusta a la realidad. Como se apreciará más adelante, el camino va flanqueado por estas cadenas, no cortando a través de ellas.

Un poco más precisas en cuanto a derrotero son las referencias publicadas por estudiosos locales. Según Risopatrón (1924: 423; ver también Latcham 1938: 9 y Mostny 1949: 180), en

"el Loa se ve un camino a $350 \mathrm{~m}$ de la orilla del mar [se refiere al margen occidental del valle], que atraviesa encañadas o recorre otras en toda su lonjitud, sigue rectamente al $N$ hasta llegar a Guantajaya [Región de Tarapacá]”.

Le Paige (1958: 79; ver también Salazar 2002: 177), por su parte, menciona un ramal de camino inca que desciende desde el salar de Ujina al volcán Miño, continúa por el valle del Loa hacia el sur, pasa al este del Cerro Pajonal por Conchi Viejo, bifurcándose en un camino que va al oeste de los cerros Paqui, Atahualpa e Inca, para arribar a Chuquicamata, y en otro que desciende al río Loa, llegando a Lasca (¿Lasana?), Chiu Chiu y Calama (Núñez 1999). Dado que Conchi Viejo se encuentra al oeste del Loa, es curioso que su mapa muestre al eje vial cruzando el río desde esa orilla a la opuesta a la altura de Miño y desde ese punto dirigiéndose al sur exclusivamente por la banda oriental del valle hasta Chiu Chiu (ver Le Paige 1958: Lám. XX). Existe, evidentemente, una contradicción entre la descripción de este autor y la información que entrega en su mapa.

\footnotetext{
National Geographic, mayo de 2002.
}

Por otra parte, en su mapa del Collasuyu, Raffino (1981: 80-81) hace discurrir el camino del Alto Loa desde la altura de Conchi Viejo al sur, pero sin precisar por cual banda del valle lo hace. Extrañamente, el autor ubica a las localidades de Lasana, Chiu Chiu, Cupo y Turi como jalones de la misma vía, en circunstancias que las dos primeras están en el Alto Loa ( $c a .68^{\circ} 40^{\prime}$ Long. O) y las dos últimas, en la cuenca alta del río Salado ( $c a$. $68^{\circ} 15^{\prime}$ Long. O). Finalmente, basada en parte en algunas de estas publicaciones y en parte en otros antecedentes similares, Varela (1999: Fig. 1) traza en un mapa el recorrido del camino inca del Alto Loa entre Ujina y Lasana-Chiu Chiu, haciéndolo pasar primero por la banda oriental y luego por la occidental del valle (ver también Salazar 2002: 82-83). Equivocadas o no, ninguna de estas referencias se sustenta en una investigación sistemática del camino en el terreno, deficiencia que en este artículo nos proponemos subsanar.

En cuanto a instalaciones incaicas en el Alto Loa, éstas han sido reportadas (o revaluadas como tales) por los arqueólogos sólo desde hace algo más de una década (Berenguer 1994: 10). A principios del siglo pasado, Risopatrón (1924: 424) localiza en el trayecto a Chiu Chiu y Calama, un sitio que denomina "Incaguasi", situándolo a 18 $\mathrm{km}$ al sur de Conchi y definiéndolo como "posta abandonada". Hace unos años, este sitio fue inspeccionado por otros colegas, quienes infirieron su afiliación incaica sobre la base de las características arquitectónicas del edificio y de fragmentos cerámicos encontrados en superficie (Cornejo 1995). En la carta Conchi, de escala 1: 50.000, el topónimo "Incaguasi" aparece a unos $15 \mathrm{~km}$ al sur de la Posta de Santa Bárbara y, contrariamente a lo señalado por Varela (1999: Fig. 1), quien en su mapa lo ubica al este del Loa, se refiere a un lugar situado al oeste del río. Poco antes, Castro (1992) había reportado como incaicos los sitios Kona Kona-1 y 2 en la localidad de Miño, y Cerro Colorado-1 y 2 en las proximidades del Cerro Cirahue, que es parte del cordón Cerro Colorado. Más recientemente, Núñez (1999), con motivo de un estudio de impacto ambiental, encuentra 10 sitios incaicos relacionados con la explotación de óxidos de cobre en el Mineral El Abra, a sólo $24 \mathrm{~km}$ al oeste del valle del Loa. Estos sitios, así como otros seis encontrados con posterioridad en el mismo mineral y en el vecino Conchi Viejo, están siendo investigados por Salazar (2002). 
En suma, al momento de formular nuestro proyecto de investigación en 2000, existían importantes razones de índole científica para proponer una investigación arqueológica detallada de esta ruta incaica, incluyendo diferentes menciones a un camino inca, varios antecedentes sobre instalaciones incas de diversas tipologías e importantes vacíos de información o contradicciones sobre el trazado y las características de este eje vial. Incidentalmente, digamos que en una prospección de senderos troperos del Período Intermedio Tardío (ca. 950-1400/1450 DC), efectuada en 1994 en el Sector Santa Bárbara, habíamos localizado y descrito varios segmentos de una vía incaica situada entre la posta epónima y el sitio Cerro Colorado-1 (Berenguer 1994, 2004a). Como se constatará más adelante, la prospección de ese tramo de $11.5 \mathrm{~km}$ constituyó un verdadero "piloto" para la presente investigación.

Hay varias interrogantes básicas que deseamos responder en este artículo: 1) en definitiva, ¿por dónde corre el camino inca en el Alto Loa?; 2) ¿qué características constructivas presenta?; 3) ¿cuáles son los factores topográficos que explican su trazado?; 4) ¿de qué manera su visibilidad y estado de conservación varían con las condiciones ambientales de las zonas que atraviesa?; 5) ¿qué sitios y rasgos se hallan asociados al camino?; 6) ¿es el arte rupestre un componente de la vialidad incaica como lo fue de los senderos caravaneros en tiempos preincaicos?; 7) ¿cómo se relaciona el camino con vías de circulación anteriores, contemporáneas o posteriores que hicieron uso de la ruta del Alto Loa?, y 8) ¿qué conexiones presenta la arteria con otras vías y localidades contemporáneas con ella, dentro y fuera del valle? A la larga, responder estas preguntas contribuirá a expandir, corregir o ratificar conclusiones y observaciones de otros investigadores sobre la unidad y diversidad del Qhapaqñan en los Andes.

\section{El área de estudio}

El área que denominamos "Alto Loa" pertenece al sector superior de la cuenca hidrográfica del río Loa, pero debe enfatizarse que es un concepto menos incluyente que el de "Loa Superior", al cual a veces equivocadamente se le asimila. Este último se refiere a toda la cuenca alta del Loa, incluyendo no sólo el curso superior de este río, sino también la totalidad de la hoya del río Salado, que es su principal afluente. El concepto de Alto
Loa, en cambio, es mucho más restringido: se refiere estrictamente al brazo superior del río Loa. Como tal, se extiende desde las nacientes de este curso fluvial, en la localidad de Miño, hasta su confluencia con el río Salado.

El Alto Loa es un valle intermontano de origen tectónico de casi $150 \mathrm{~km}$ de largo y unos 20 a 25 $\mathrm{km}$ de ancho máximo. Nace a casi $4000 \mathrm{~m} . \mathrm{snm}$ en un amplio anfiteatro limitado por serranías, desde las cuales desciende un extenso pedimento árido conformado por el carcanal Mal Paso en su parte superior y detritos de diversos orígenes y naturaleza en su parte inferior. Muchos de estos campos de carcas se hallan disectados por quebradas secas o de escurrimiento estacional que confluyen en el río Miño que, al unírsele poco más abajo el estero Nacimiento, toma el nombre de río Loa. Desde allí, el valle corre de norte a sur por una rampa volcánica de no más de $1^{\circ}$ de pendiente, encajado entre dos largas cadenas montañosas: al oeste, la Cordillera del Medio y al este, la Cordillera Andina (Figura 1).

\section{Relieve y características litológicas}

La Cordillera del Medio -donde se encuentran las mayores reservas de cobre del mundo- está constituida principalmente por rocas fundamentales mesozoicas del Jurásico y Cretácico Inferior, con intrusiones de rocas plutónicas como el cordón Cerro Colorado (4466 m.snm) y el macizo de granodiorita del Mineral de Chuquicamata. Desde un punto de vista morfológico, se extiende desde el Cerro Puntamalla (4400 m.snm) por el norte hasta los Cerros de Paqui (4589 m.snm) por el sur. Una de sus máximas elevaciones es el Cerro Pajonal (4550 m.snm), en cuyas proximidades se hallan el actual Mineral El Abra y el prehispánico Complejo Minero San José del Abra. Es una cadena continua, pero franqueable a través de unos pocos pasos.

La Cordillera Andina, en tanto, es un cordón volcánico activo más nuevo y de mayor altitud que la Cordillera del Medio, con estrato-volcanes de edad pleistocénica. Con un zócalo de alrededor de $3800 \mathrm{~m}$ de altitud, sus más altos nevados alcanzan entre 5000 y 6000 m.snm. De éstos pueden mencionarse los volcanes Miño (5661 m.snm), Aucanquilcha (6176 m.snm), Polán (5362 m.snm), Gordo (5196 m.snm), Chela (5644 m.snm), Palpana (6023 m.snm), Cebollar (5716 m.snm), 


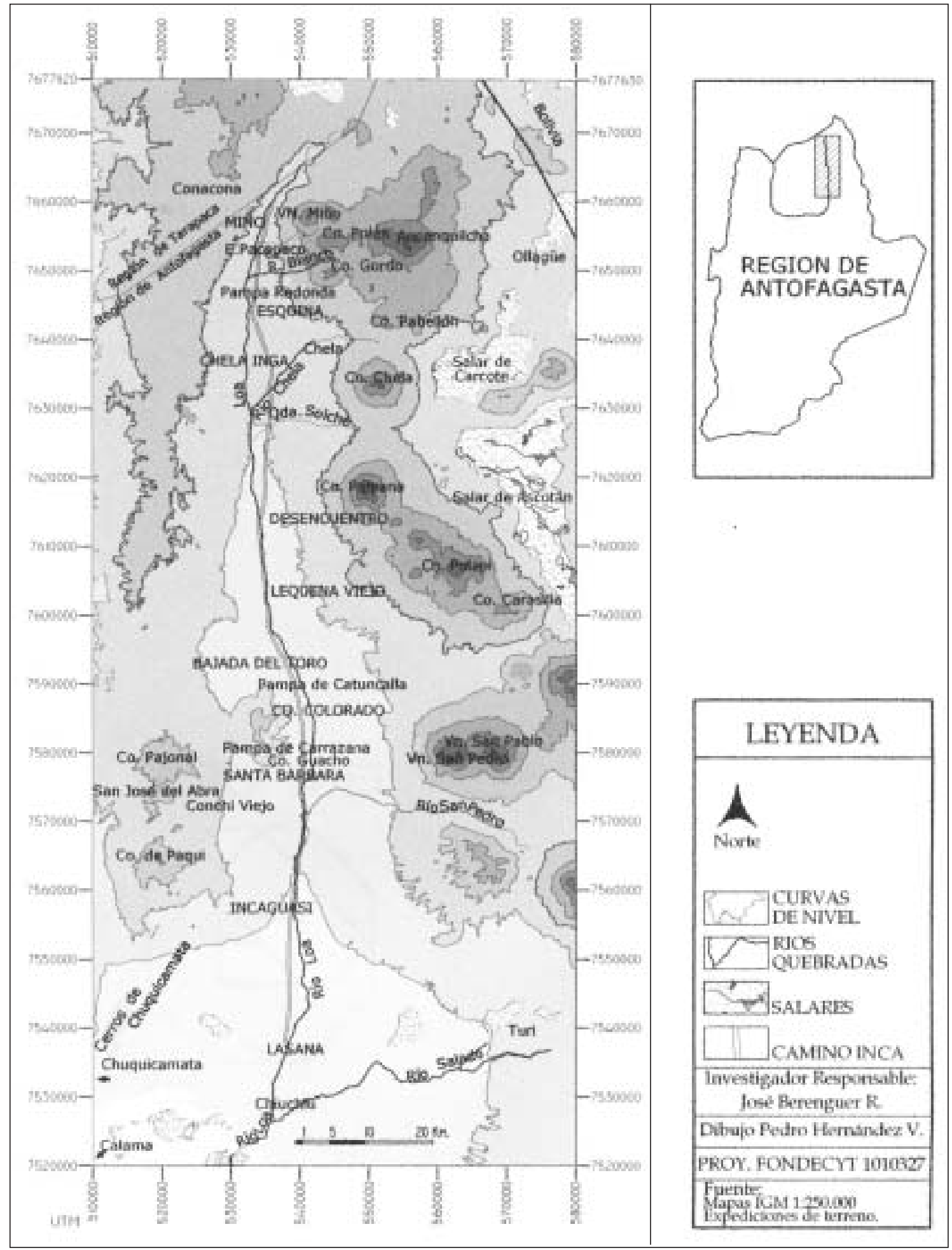

Figura 1. Mapa del valle del Alto Loa con el trazado del camino inca entre Miño y Lasana. 
Polapi (5949 m.snm), Carasilla (5040 m.snm), San Pedro (6145 m.snm) y San Pablo (6092 m.snm). Varios pasos comunican al Alto Loa con el oriente a través de este cordón.

De ambas cadenas montañosas descienden hacia la fosa del Loa sendos planos inclinados. El plano occidental es una penillanura árida de declive al este, cruzada por numerosas estribaciones y cerrillos desprendidos de la Cordillera del Medio, así como por cerca de 64 quebradas de escurrimiento estacional, algunas someras y otras bastante profundas. El plano oriental, en tanto, es una penillanura árida de declive al oeste. La atraviesan varias coladas de lava extendidas en abanico, así como unas 55 quebradas de características similares a las de la banda opuesta. Quebradas, estribaciones y coladas delimitan grandes y pequeñas llanadas -algunas conformando especies de ensenadas- conocidas localmente como "pampas". Por ellas corrió el camino inca.

Las rocas volcánicas más importantes del área corresponden a ignimbritas dacíticas y riolíticas (Ramírez y Huete 1981). Estos flujos piroclásticos soldados, de color blanquecino el superior (dacítico) y rojizo o anaranjado el inferior (riolítico), forman parte del volcanismo terciario (Mioceno Superior-Plioceno) e incluyen niveles basales de conglomerados, posiblemente fluviales. Las placas ignimbríticas de las pampas occidentales se encuentran en su mayor parte cubiertas por depósitos de piedemonte, consistentes en diferentes tipos de rocas volcánicas e intrusivas (Pino 1998 Ms). En el primer caso, son el resultado de procesos de meteorización o rotura in situ $\mathrm{y}$, en el segundo, de procesos de desintegración, remoción y transporte desde la Cordillera del Medio bajo la forma de bolas de granito y arenas. Las placas de ignimbritas orientales, por otro lado, presentan una cubierta en su mayor parte formada por andesitas y basaltos, presumiblemente asociada a procesos coluviales y aluviales holocénicos derivados de los conos volcánicos vecinos. Son campos de lavas cuaternarias originados en grandes coladas en abanico. Cuando no hay materiales sueltos como éstos, aflora en ambas bandas roca firme o no alterada, bajo la forma de planchones ignimbríticos en proceso de denudación y peneplanización, localmente conocidos como "carcas". En algunos sectores, como en las pampas Catuncalla, Carrazana y Cerro Guacho, quedan aún remanentes de las ignimbritas superiores o dacíticas; se trata de "planchadas" (sensu Niemeyer y Rivera 1983) y "dorsos de ballena" (sensu Whittow 1988), que son resultado del ataque del viento dominante, armado con arenas y otros materiales particulados. En varios otros sectores, en cambio, el proceso de erosión de estas tobas se halla completado, asomando únicamente planchadas de las ignimbritas inferiores o riolíticas (p.e., Miño, Pampa Redonda, Quebrada Solche, Desencuentro). Al final de este artículo se comprenderá que la naturaleza y características de estos piedemontes son importantes para entender el estado de preservación o degradación de la vialidad incaica en el área.

Aguas abajo del Cerro Añil, por ambas bandas del valle, sobreyacen a las tobas del volcanismo fisural del Terciario materiales lacustres pleistocénicos, que constituyen la serie más reciente de sedimentación. En estos sectores, el piedemonte está formado por planchadas de calizas y por regolitos producto de la alteración in situ de estas rocas, como también por clastos subangulares y arenas procedentes de los flancos montañosos, operando estas pampas como genuinas playas de sedimentación.

El río Loa corre en su mayor parte encajonado en una profunda hendidura de paredes verticales, labrada a expensas de las placas ignimbríticas de la zona. Desprendimientos sucesivos de bloques de estas paredes han formado en muchos sectores taludes de derrubios de falda más o menos continuos. Las quebradas tributarias más profundas también han tallado gargantas, pero salvo la del río San Pedro, carecen de taludes de escombros o éstos exhiben un desarrollo considerablemente menor y bastante más discontinuo. Al sur del embalse de Conchi, la garganta del Loa está incisa en sedimentos lacustres y en tobas de la formación riolítica subyacente (Ochsenius 1974-75: Lám. II). Como forma de paisaje, el cañón desaparece unos $6 \mathrm{~km}$ aguas abajo de la localidad de Lasana, en el sector Chacras Viejas, al ingresar el río a la extensa cuenca paleolacustre de Chiu ChiuCalama (Ochsenius 1974-75: Lám. IV).

\section{Hidrología}

El régimen de este río ha sido descrito como principalmente nivopluvial, con crecidas violentas en verano y mayores caudales en otoño e invierno (Romero y Rivera 1995). En el Alto Loa, en par- 
ticular, el río tiene una muy importante recarga de renovación de tipo primario o de aguas nuevas, que está asociada a las precipitaciones que ocurren con cierta regularidad durante la temporada estival en la Cordillera Andina, a una altitud mayor a 4000 m.snm (ESSAN 1992). Es precisamente a lo largo de este curso donde el Loa recibe por el este a sus afluentes: los esteros Nacimiento y Paco Paco y los ríos Chela y San Pedro (de Inacaliri). Vale decir, el Loa es en su brazo superior un río bien dotado en recursos hídricos, sobre todo si se le compara con la menguada escorrentía que caracteriza a los cursos de agua del norte de Chile, cuestión logísticamente vital en una ruta de tráfico que atraviesa fajas tan desérticas.

\section{Clima y vegetación}

El clima de esta zona varía de norte a sur desde uno caracterizado en la clasificación de Koeppen como Desierto Marginal de Altura (BWH) a otro tipificado como Desértico Normal (BW) (IGM 1990: Fig. 11). Las precipitaciones ocurren comúnmente durante el verano del hemisferio austral, mientras que el resto del año es por lo general seco (ESSAN 1992). Se observa una clara y radical disminución de la pluviosidad con el decremento altitudinal. De casi $150 \mathrm{~mm}$ en Collaguasi (4700 m.snm) y más de $100 \mathrm{~mm}$ en la Captación Lequena (3300 m.msm), se pasa a valores cercanos a $25 \mathrm{~mm}$ en el embalse de Conchi (2920 m.snm) y a montos insignificantes en Chiu Chiu (2545 m.snm) (Consecol 1988: Fig. 1.4). Las lluvias decrecen también de este a oeste. La Cordillera del Medio, por ejemplo, presenta precipitaciones menores y más irregulares que los relieves de alturas equivalentes de la Cordillera Andina (ESSAN 1992).

De norte a sur, es posible distinguir tres principales pisos vegetacionales a lo largo del Alto Loa, que varían marcadamente con la gradiente altitudinal e isoyética. Primero, el Piso Altoandino, que se extiende desde unos 4100 m.snm en Miño, hasta alrededor de los $3750 \mathrm{~m} . \mathrm{snm}$ en Chela. Corresponde a una vegetación caracterizada por gramíneas cespitosas en mechón, como la cebadilla (Stipa venusta) y la paja brava (Festuca chrysophylla), y por plantas en cojín, como la llareta (Azorella compacta) y la llaretilla (Pycnophyllum sp.), con algunas intrusiones de arbustos bajos de follaje reducido (tola), que pueden alcanzar mayor altura y densidad en localizaciones cercanas al río. Segundo, el Piso Andino Inferior, que abarca aproximadamente desde los 3750 m.snm en Chela, hasta los 3300 m.snm en Condoroma. Es una vegetación fundamentalmente arbustiva, dominada por Fabiana densa (tara, checal) y Baccharis boliviensis (lejía, pesco tola), que ocupa con variable densidad las planicies en toda su extensión. Tercero, el Piso Subandino, que se extiende más o menos desde los 3300 m.snm en Condoroma, hasta los 3100 m.snm en Santa Bárbara. Se caracteriza por una cobertura extremadamente rala, dominada por el arbusto Acantholippia punensis (rica-rica). Varias de las especies de estos tres pisos vegetacionales son leñosas y resinosas, y deben haber servido como combustible para los viajeros. Por debajo de los $3100 \mathrm{~m}$, donde las precipitaciones son escasas o virtualmente nulas $(0.1 \mathrm{~mm})$, se extienden pampas sin vegetación alguna.

\section{Metodología}

Para localizar vías incaicas en el área de estudio diseñamos una estrategia de investigación que, inicialmente, contempló el uso combinado de análisis de documentos históricos, exégesis toponímicas y análisis aerofotogramétrico. Restricciones de espacio impiden extenderse en los detalles de esta etapa exploratoria realizada en gabinete. Baste decir que el análisis cruzado de esta información nos llevó a conjeturar que -contrario a lo que plantean otras fuentes- entre Miño y algún punto no determinado del trayecto hacia el sur, el camino inca del Alto Loa corre por la banda oriental del valle, y que, sólo a partir de ese punto hasta Lasana, lo hace por la banda occidental. Así, nuestra prospección arqueológica pasó a ser, en parte, una verificación en terreno de esta hipótesis de trabajo. Una vez concretada la etapa exploratoria de gabinete, planificamos las operaciones de campo. La prospección a pie que realizamos hace 10 años del tramo Cerro Colorado-Santa Bárbara (aprox. 10\% del trayecto MiñoLasana), así como las prospecciones de caminos incaicos realizadas con diferentes modalidades por otros investigadores en otras partes de la región, permitieron tomar una serie de decisiones tácticas de utilidad para el presente reconocimiento. De hecho, nos condujeron a planificar una prospección pedestre, intensiva y de cobertura total. 


\section{Criterios para identificar vías}

Es importante aclarar que en este artículo el término "ruta" se usa como equivalente de itinerario o derrota de un viaje y es, en cierto modo, abstracta o intangible. A esto nos referimos cuando hablamos de la "ruta del Alto Loa". El término "vía", en cambio, se utiliza para referirse genéricamente a cualquier curso de tránsito humano físicamente visible en el terreno (Hyslop 1984: 13), con independencia de su ancho, funcionalidad específica y características constructivas. El lector deberá tener en cuenta estas precisiones a lo largo del trabajo. Una ruta puede tener ya sea trazas separadas o traslapadas de varias vías de una misma o diferente naturaleza o época. Existen tres posibles tipos de vías a considerar: los caminos, los senderos y las sendas (Berenguer 2004a).

Un camino es una vía formal que presenta alguna evidencia de planificación y construcción (Earle 1991). Su trazado supera grandes obstáculos y supuestamente da como resultado redes menos redundantes que los senderos y a la larga menos costosas para el transporte. Los principales criterios empíricos que usamos para identificar una vía como camino incaico, fue que mostrara evidencias de haber sido utilizada durante el Horizonte Tardío o Inca y que su traza se relacionara físicamente con asentamientos construidos o utilizados por los incas (Hyslop 1984). En el primer caso, esto fue establecido sobre la base de cerámica de superficie y, en el segundo, por este último material y por características arquitectónicas incaicas (p.e., tipo de mampostería, vanos trapezoidales, presencia de recintos perimetrales compuestos). Otro criterio fue su rectitud: se dice que los caminos incaicos siguen la línea recta, tanto en los llanos como en los terrenos quebrados (Romero 1978), aseveración que, aunque relativizada por Hyslop (1984), es sostenible en nuestra región cuando estos caminos se comparan con las sinuosas vialidades troperas. Por otra parte, sabíamos desde la prospección de 1994 que el trazado del camino puede desaparecer y reaparecer numerosas veces (por disturbaciones naturales o antrópicas), por lo tanto nuestra expectativa era encontrar sólo segmentos de él (ver Berenguer 1994). Un segmento fue operativamente definido como un trecho de vía observable por un prospector, con independencia de su estado de preservación. En todo caso, prácticamente la totalidad de la superficie a prospectar entre Miño y
Lasana es arena, roca desnuda o roca disgregada con poca vegetación, por lo que esperábamos una alta observabilidad de los sitios y rasgos laterales, incluso de las vías. En el caso de estas últimas, tuvimos como referentes mínimos a ubicar, los segmentos de caminos de 3-4 m de ancho y baja inversión de trabajo encontrados por Hyslop (1984: Figs. 3.3 y 3.7; también Hyslop y Rivera 1984) y Niemeyer y Rivera (1983) en el "Despoblado de Atacama”, por Lynch y Núñez (1994: Figs. 4a y 8) entre Turi y Catarpe, y por nosotros mismos entre Cerro Colorado-1 y la Posta de Santa Bárbara (Berenguer 1994, 2004a: Figs. 6.14, 6.15).

El criterio que empleamos para identificar empíricamente una vía como sendero, en tanto, fue que ésta apareciera como un trazado informal, redundante y más geomórfico que un camino y que impresionara más como producto del simple y reiterado trajín de personas y animales, que de la planificación o la inversión de trabajo (Trombold 1991: 3; ver también Hyslop 1991: 29). Para identificar senderos troperos, se buscaron los típicos surcos múltiples y ondulantes (p.e., los típicos "rastrillados" y "trenzados") que dejan sobre el terreno las recuas cuando transitan recurrentemente por una ruta del desierto (Núñez 1976: 180, 1999: Figs. 14 y 15, fotos superiores; Berenguer 1999: 35, 2004a: Fig. 5.3). Cada surco puede alcanzar hasta $30 \mathrm{~cm}$ de ancho y, en conjunto, pueden dar origen a huellas de $70 \mathrm{~m}$ de ancho, incluso más.

Finalmente, una senda es una huella de trazado informal, redundante y geomórfico de aproximadamente 30 a $50 \mathrm{~cm}$ de ancho que resulta del recurrente paso de transeúntes. Su evaluación como parte de la vía depende de su empalme con extremos de segmentos del camino, y con suerte, del hallazgo de estructuras laterales al camino que conserven mampostería incaica y cerámica del Horizonte Tardío.

Hay otros tres conceptos viales que requieren definición: desvío, variante y enlace. Un desvío es cualquier camino que se desprende de la vía longitudinal, en que, para proseguir viaje, es necesario volver al punto de desprendimiento. Una variante, en cambio, es un camino alternativo que se desprende de la longitudinal para unirse a ella más adelante. Por último, un enlace es un camino que conecta la vía longitudinal con otra longitudinal o con un desprendimiento de esta última. Se trata, como puede verse, de conceptos 
más interpretativos que los de camino, sendero y senda, ya que operan como hipótesis de trabajo hasta bien avanzado el proceso de investigación. Por lo general, sólo pueden confirmarse como tales una vez que se conoce el trazado y la extensión global de la red. También debemos señalar que, en este artículo empleamos los términos "camino", "arteria" y "eje vial" como sinónimos, es decir, sin connotaciones jerárquicas que presupongan principalidad o secundariedad de las vías.

\section{Diseño de la prospección}

Abordamos la prospección del trayecto MiñoLasana tanto desde un enfoque micromorfológico como macromorfológico (Trombold 1991: 4-5). Por una parte, nos interesaba registrar elementos tales como ancho de la arteria, rectitud, preparación de la superficie, depresionamientos, detalles constructivos u obras (rampas, muros de contención, escalinatas, sistemas de drenaje, banquinas) y otros rasgos viales (p.e., puntos de conexión con otras vías, asentamientos laterales, apilamientos de piedras de origen antrópico, arte rupestre). Por otra parte, nos interesaba registrar información acerca de la extensión de la red dentro del área de estudio o más allá de ésta, la función de los puntos que conecta, la contemporaneidad de los puntos conectados y la configuración global del sistema vial. Estos enfoques opuestos, pero complementarios, determinaron en gran parte nuestros procedimientos de registros y dispositivos de medición.

Se diseñaron dos tipos de formularios para levantar información en terreno, uno para Caminos (55 entradas) y otro para Sitios y Rasgos Asociados al Camino (72 entradas). Cada hoja de formulario corresponde a un "punto de interés" a lo largo del trayecto y de los tramos en que éste se subdivide, cuyo código de designación consiste en dos letras mayúsculas seguidas de un guión y un número de orden. ${ }^{8}$ Las letras elegidas carecen de significado relevante y, por lo general, varían día a día; los números, en cambio, siempre varían dentro de cada par de letras y su secuencia sólo refleja el orden en que los puntos fueron registrados. Un "punto de interés" fue operativamente definido como un lugar donde la vía cambia de aspecto o

\footnotetext{
8 La excepción la constituyen los sitios designados como "SBa-n", que corresponden a codificaciones nuestras, pero anteriores a esta prospección.
}

de visibilidad, una cuesta o terreno en pendiente, un cruce o traslape con otra vía, una conexión vial, un lugar donde hay uno o más montones artificiales de piedras, un hallazgo de fragmentos cerámicos, un asentamiento o cualquiera otra estructura adyacente al camino. Un trayecto fue definido como la distancia recorrida por la vía entre dos grandes instalaciones incaicas o entre una instalación inca y un centro prehispánico local regionalmente importante. Los tramos, en cambio, son simples subdivisiones del trayecto y están encabezados por un asentamiento prehispánico, histórico o mixto.

Para describir expeditivamente sobre la marcha el grado de visibilidad de un segmento de camino inca en cada observación puntual, se ideó una escala ordinal de cinco niveles de visibilidad: Nítido ( $\mathrm{N}=$ se observa con suma claridad), Menos Nítido (MN=se observa con claridad), Regular ( $\mathrm{R}=$ se observa con dificultad), Menos que Regular (MR=se observa con suma dificultad) e Invisible ( $\mathrm{I}=\mathrm{es}$ inobservable o se convierte en un sendero tropero o en una senda).

La información recabada en los formularios fue vaciada a una base de datos en formato de archivo $\mathrm{DBF}$, construida mediante el software APPROACH de Lotus. En seguida, se construyó un Sistema de Información Geográfica (SIG) sobre cartografía digital escala 1: 250.000 del Instituto Geográfico Militar (IGM, cartas Collacagua, Ollagüe y Calama). Otro SIG escala 1: 50.0000 se encuentra aún en preparación. Se escogió el programa AUTOCAD MAP para trabajar la cartografía y generar los SIG. Sobre la cartografía base se vaciaron las coordenadas de los puntos de interés arrojadas por el GPS, trazándose los segmentos de camino y otros elementos relacionados con éste. De esta manera es posible asociar gran parte de la base de datos, incluyendo textos (informes, publicaciones) y dibujos (planos, dibujos, fotografías), con puntos específicos en el mapa.

Es pertinente aclarar que, al registrar y describir los asentamientos encontrados a lo largo de la vía, evitamos utilizar denominaciones originadas en la documentación etnohistórica sobre los incas, tales como "tambo", "tambillo", "chaskiwasi”, entre otros. Usualmente estas categorías de asentamiento son difíciles de discriminar en forma $a$ priori, al menos en una etapa tan inicial de la investigación. Siguiendo en parte a Niemeyer y 
Rivera (1983), optamos por clasificarlos de manera neutra en Menores (hasta dos recintos), Medianos (hasta 10 recintos) y Mayores (con más de 10 recintos). La tarea de calzar estos conceptos con las denominaciones etnohistóricas fue postergada para etapas posteriores del proyecto, como parte de un trabajo de índole interpretativa que se sustente en un análisis más fino de la arquitectura y de los contextos recuperados en las recolecciones y excavaciones.

Las coordenadas Universal Mercator Transversal (UTM) y la elevación o altitud de cada punto de interés a lo largo del trayecto fueron establecidas mediante el Sistema de Posicionamiento Global (GPS), con un instrumento marca Garmin Etrex de 12 canales. Una precisión entre 9 y 15 m para las UTM fue considerada aceptable. Se trabajó con el Datum La Canoa 1956. El "rumbo magnético" del camino en cada punto fue medido con una brújula Brunton. El registro fotográfico se efectuó con una cámara digital Olympus C-3000Zoom, en modo de grabación High Quality (2048 x 1536 pixeles).

A fin de mantener el control de nuestra posición sobre la marcha con relación a las previsualizaciones de posibles segmentos de camino inca obtenidas en el análisis aerofotogramétrico (rasgos lineales), se preparó un rollo con fotocopias de fotos aéreas verticales solapadas del Servicio Aerofotogramétrico de la Fuerza Aérea de Chile (SAF 81 CH-30: No 022651 / 022587), que fueron montadas de norte a sur a lo largo de toda el área de estudio. En ellas se colocó el nombre de las localidades, quebradas, pampas y otros topónimos importantes. Este fotomapa aseguró un constante cotejo entre los rasgos lineales apreciables en las fotos aéreas, la morfología real del terreno que íbamos recorriendo y las coordenadas UTM y cotas de elevación que nos iba entregando el GPS.

Con el objeto de aproximarse a la cronología, uso y actividades en la vía, se practicaron sobre la marcha colectas sistemáticas de fragmentos cerámicos de superficie en cada punto de interés donde los hubiera, excepto en los asentamientos, ya que el estudio de estos últimos -incluyendo la recolección sistemática de materiales superficiales- se pospuso para la fase de excavaciones del proyecto. A estas alturas de la investigación, sin embargo, contamos con análisis de estas últimas colecciones, de manera que sus resultados estuvieron bajo consideración en este artículo (Uribe y Cabello 2004 Ms).

La prospección de los tramos que aparecían más complejos y complicados de acuerdo a las fotos aéreas, la cartografía y nuestra propia experiencia en terreno (Miño-Esquina, Esquina-Chela Inga, Chela Inga-Desencuentro y Desencuentro-Lequena Viejo), fue llevada a cabo con la ayuda de lugareños (Nicolás Aimani, estanciero de Pastos Grandes y Marino Gabriel, estanciero de Chela). El conocimiento empírico de estos habitantes del área resultó ser tan fino, que usualmente fueron capaces no sólo de ubicar la vía, sino también de discriminar sin muchos titubeos entre camino inca, huellas troperas y huellas de carretas, aunque obviamente no son infalibles.

\section{Derrotero del camino}

Limitaciones de espacio impiden extenderse en una descripción pormenorizada del derrotero seguido por el camino. Por la misma razón, de los 285 puntos de interés registrados a lo largo de la prospección, únicamente aquellos mencionados en esta sección, en las secciones siguientes y en los pies de ilustraciones aparecen en la Tabla 1. Todos los topónimos que figuran en el texto y en la tabla han sido tomados de las respectivas cartas 1: 50.000 del IGM. Debido a restricciones de escala, algunos de ellos no aparecen en el mapa de la Figura 1, por lo que se recomienda acudir a la cartografía de referencia para encontrar su localización. Se identificaron nueve tramos de camino inca a lo largo del trayecto Miño-Lasana, los que se exponen en seguida de manera muy sucinta (Tabla 1).

El Tramo 1 (Miño-Esquina) va de norte a sur por la banda oriental del Loa y se extiende desde MI2 (Kona Kona-2) hasta la quebrada Esquina, con exclusión de esta última (Cartas IGM Volcán Miño [4230-B/7] y Chela [4230-B/15]; Fotogramas SAF 81 CH-30 S4-5 n 022671-022590). Tiene una longitud de $16.06 \mathrm{~km}$.

El Tramo 2 (Esquina-Chela Inga) va de noroeste a sureste por la banda oriental del Loa y se extiende de la quebrada Esquina (RE-5) al río Chela (Carta IGM Chela [4230-B/15]; Fotogramas SAF 


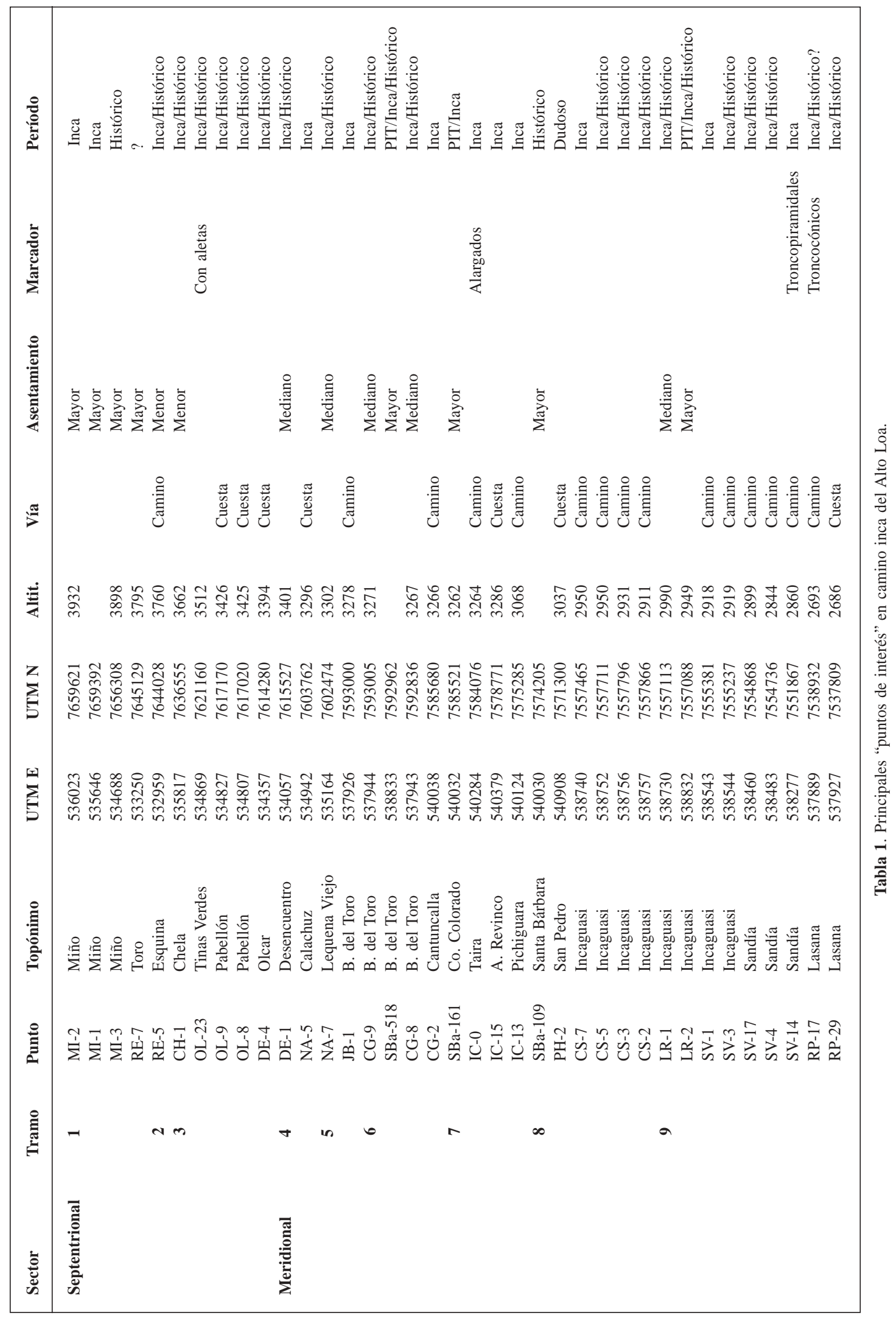


$81 \mathrm{CH}-30 \mathrm{~S} 4-5 \mathrm{n}^{\circ}$ 022591-022663). Tiene una longitud de $8.01 \mathrm{~km}$ y desde Miño, acumula una distancia recorrida de $24.07 \mathrm{~km}$.

El Tramo 3 (Chela Inga-Desencuentro) va en un principio de noreste a suroeste y luego de norte a sur por la banda oriental del Loa, acercándose gradualmente al río. Se extiende desde el río Chela (CH-1) hasta el cruce del río Loa en Desencuentro (Cartas IGM Chela [4230-B/15] y Cerro Palpana [4230-B/24]; Fotogramas SAF 81 CH-30 S4-5 $\mathrm{n}^{\circ}$ 022663-022655). Tiene una longitud de $22.93 \mathrm{~km}$ y acumula una distancia recorrida de $47 \mathrm{~km}$.

El Tramo 4 (Desencuentro-Lequena Viejo) va de norte a sur por la banda occidental del Loa y se extiende entre Desencuentro (DE-1) y la quebrada Lequena, más o menos a la altura de Calachuz (Carta IGM Cerro Palpana [4230-B/24]; Fotogramas SAF 81 CH-30 S4-5 no 022655022650). Tiene una longitud de $11.73 \mathrm{~km}$ y acumula una distancia recorrida de $58.73 \mathrm{~km}$.

El Tramo 5 (Lequena Viejo-Bajada del Toro) va de norte a sur por la banda occidental del Loa y se extiende desde la quebrada Lequena (NA-7) hasta la quebrada Las Cruces (Cartas IGM Cerro Palpana [4230-B/24] y Estación San Pedro [4230-B/33]; Fotogramas SAF 81 CH-30 S4-5 no 022650022706). Tiene una longitud de $10.15 \mathrm{~km}$ y acumula una distancia recorrida de $68.88 \mathrm{~km}$.

El Tramo 6 (Bajada del Toro-Cerro Colorado) va de norte a sur por la banda occidental del Loa y abarca desde la quebrada Las Cruces (CG-9) hasta el Cerro Cirahue (Carta IGM Estación San Pedro [4230-B/33]; Fotogramas SAF 81 CH-30 S4-5 $\mathrm{n}^{\circ}$ 022706-022707). Tiene una longitud de 7.78 $\mathrm{km}$ y acumula una distancia recorrida de 76.66 $\mathrm{km}$. En Bajada del Toro, comprobamos la existencia de un desvío hacia el este que conecta el camino y el sitio CG-9 con el caserío local SBa518 , situado a $2 \mathrm{~km}$ de distancia en el interior del cañón río Loa.

El Tramo 7 (Cerro Colorado-Santa Bárbara) va en general de norte a sur por la banda occidental del Loa. Comienza en el Cerro Cirahue (SBa-162) y culmina en la Rinconada de Santa Bárbara (Carta IGM Estación San Pedro [4230-B/33]; Fotogramas SAF 81 CH-30 S4-5 $n^{\circ}$ 022707-022710). Tiene una longitud de $11.5 \mathrm{~km}$ y acumula una distancia recorrida de $88.16 \mathrm{~km}$. En el asentamiento SBa162 puede haber habido un desvío al oeste del camino hacia el Cerro Cirahue, en cuyo flanco norte existe una vía de características similares a la arteria troncal, pero no hemos encontrado la vía de conexión.

El Tramo 8 (Santa Bárbara-Incaguasi) se extiende entre Santa Bárbara (SBa-109) e Incaguasi (Cartas IGM Estación San Pedro [4230-B/33] y Conchi [4230-B/42]; Fotogramas SAF 81 CH-30 S4-5 no 022710-022715). Sólo tenemos constancia de que el camino va de sur a norte por la banda occidental del Loa desde unos pocos cientos de metros al norte de Incaguasi (ver más abajo). Tiene una longitud de $17.39 \mathrm{~km}$ y acumula una distancia recorrida de $105.55 \mathrm{~km}$.

El Tramo 9 y final (Incaguasi-Lasana) va de norte a sur por la banda occidental del Loa y se desarrolla entre Incaguasi (LR-1) y Lasana (Carta IGM Conchi [4230-B/42]; Fotogramas SAF 81 CH-30 S4-5 no 022715-022719). Tiene una longitud de $19.52 \mathrm{~km}$ y acumula una distancia recorrida total de $125.07 \mathrm{~km}$. Su conexión con Lasana es un desvío al este, de igual característica a la arteria principal, que baja al valle a la altura del Pucara de Lasana y llega al sector donde se encuentra la iglesia de la localidad.

Nuestra prospección demostró que, a diferencia de lo que señalan algunos autores (Risopatrón 1924: 423; Le Paige 1958: 79), pero en parcial coincidencia con lo que contradictoriamente muestra en su mapa el propio Le Paige (1958: Lám. $\mathrm{XX}$ ), inicialmente el camino inca del Alto Loa discurre de Miño al sur por la banda oriental del valle, pasando por Esquina (RE-5) y Chela Inga (CH-1) hasta arribar a Desencuentro (DE-1), que es el lugar donde el camino vadea el río Loa $(534.310 \mathrm{E} / 7.614 .097 \mathrm{~N})$. Este punto señala la división entre lo que -de aquí en adelante- llamaremos "sector septentrional" (MiñoDesencuentro [tramos 1 a $3=47 \mathrm{~km}$ ]) y "sector meridional" (Desencuentro-Lasana [tramos 4 a $9=78 \mathrm{~km}])$.

Desde ese vado al sur, el camino discurre por la banda occidental del valle a distancias variables del río, pasando por Lequena Viejo (NA-7), Bajada del Toro (CG-9) y Cerro Colorado-1 (SBa-162), lo que estaría en conformidad con lo indicado por 
los citados autores, pero esta vez en disconformidad con lo que aparece en el citado mapa de Le Paige (1958: Lám. XX). Al sur de Taira, en la Pampa Carrazana, el camino reaparece para trasponer el Abra de Revinco, luego virar al sureste y bajar al valle del Loa poco antes de la quebrada Quinchamale, derrotero no considerado por estos autores, salvo Varela (1999: Fig. 1), quien integra información publicada por Berenguer (1994).

En el Tramo 8 (Santa Bárbara-Incaguasi) se pierde prácticamente toda traza del camino y es discutible si efectivamente pasa por SBa-109, correspondiente a las ruinas de la Posta de Santa Bárbara (Berenguer 1999: 48-49, 2004a: 311$315)$. En todo caso, lo más probable es que continúe por el fondo del valle en dirección sur y que ascienda nuevamente a las pampas occidentales por algún punto aún no detectado. La razón es que éste es el único tramo del trayecto donde el piso del valle es suficientemente ancho y topográficamente apto para trazar el camino inca por el interior del cañón. De hecho, un rasgo lineal visible en la fotografía aérea de la confluencia de los ríos Loa y San Pedro y que cruza longitudinalmente el lahar que existe en ese lugar (fotograma SAF 81 CH-30 S.4-5: $n^{\circ}$ 022711), podría corresponder a un segmento del camino. Consideraciones de seguridad, basadas en anuncios de presencia de explosivos, impidieron verificar esta hipótesis en terreno. El único dato de superficie que da cierta validez a este hipotético trazado es el punto $\mathrm{PH}-2$. Se trata de un corto segmento de camino de calidad Menos que Regular, dotado de un muro de contención y de nivelamiento para sostener la rasante. Cruza el San Pedro al este de la unión de este río con el Loa. Su atribución a la vía incaica es, sin embargo, muy insegura. En los hechos, la traza del camino inca sólo pudimos reencontrarla recién al sur del Cerro Añil, siempre por la banda occidental del valle (CS-7). En seguida, el camino pasa junto a Incaguasi (LR-1) y prosigue hasta pasar por los altos de Lasana, dirigiéndose aparentemente a Chiu Chiu y, eventualmente, a San Pedro de Atacama, posibilidades estas últimas que no fueron investigadas por estar fuera de los objetivos del proyecto. A la altura de Lasana se desprende hacia el este de la vía incaica un desvío diagonal que conduce directamente al pucara epónimo.

\section{Características constructivas}

Nuestra investigación evidenció que el camino inca del Alto Loa dista mucho de las amplias calzadas empedradas, con banquinas, caminos colaterales, muros en los costados, enrasamientos, adoquinados o emplantillados, sistemas de drenaje y de seis a $16 \mathrm{~m}$ de ancho que caracterizan al Qhapaqñan en diversas partes de Ecuador, Perú y Bolivia (Hyslop 1984: Figs. 2.2, 5.3, 15.1, 15.6, 15.9, 15.17, 17.2, 17.4; Hyslop y Rivera 1984: 39; Martin $2004 \mathrm{Ms}$ ). En nuestro caso se trata, más bien, de una modesta huella de $4 \mathrm{~m}$ de ancho como promedio, construida por lo general mediante un simple despeje de piedras hacia los lados de la vía, formando rebordes que parecen ser más el producto de la remoción que de una intencionalidad propiamente constructiva. En algunos segmentos, uno o los dos lados presentan hileras continuas o discontinuas de piedras y en otros ni siquiera eso. Seguramente, estas demarcaciones servían para delinear el derrotero en trechos donde la traza del camino se tornaba difícil de seguir (Lynch 1995-1996: 191).

Al igual que en el "Despoblado de Atacama" (Hyslop y Rivera 1984: 36), la arteria incaica del Alto Loa posee diferentes apariencias en distintas localizaciones. Sus características constructivas varían según discurra sobre superficie de arena, de roca sólida o de roca disgregada. Estos son los únicos tipos de superficie presentes en el área, aunque en muchos trechos hay combinaciones de dos o tres de estos sustratos. En zonas arenosas, como en pampa Cuestecilla (p.e., CG-2), los constructores de la vía modificaron la superficie del terreno cavando una leve depresión lineal (Figura 2a). Una trinchera de $0.50 \mathrm{~m}$ de ancho por $7 \mathrm{~m}$ de largo cavada transversalmente por nosotros en un segmento de este tipo (CG-13), mostró que la depresión alcanza $6.5 \mathrm{~m}$ de amplitud y $26 \mathrm{~cm}$ de profundidad máxima, pero que la superficie efectivamente apisonada por el tránsito cubre tan sólo los $3 \mathrm{~m}$ centrales de la traza. Este dato constituye un aporte neto de la presente investigación al conocimiento de la variabilidad de las formas constructivas del Qhapaqñan. Por otra parte, en zonas de roca desnuda (p.e., JB-1, AB-11), los constructores de la vía se limitaron a dejar la superficie intacta (Figura 2b) o a ribetear con piedras sus bordes. En zonas de roca disgregada (p.e. MI-8, CS-3), tendieron a remover las piedras del centro de la vía, dejando rebordes o falsos muros latera- 


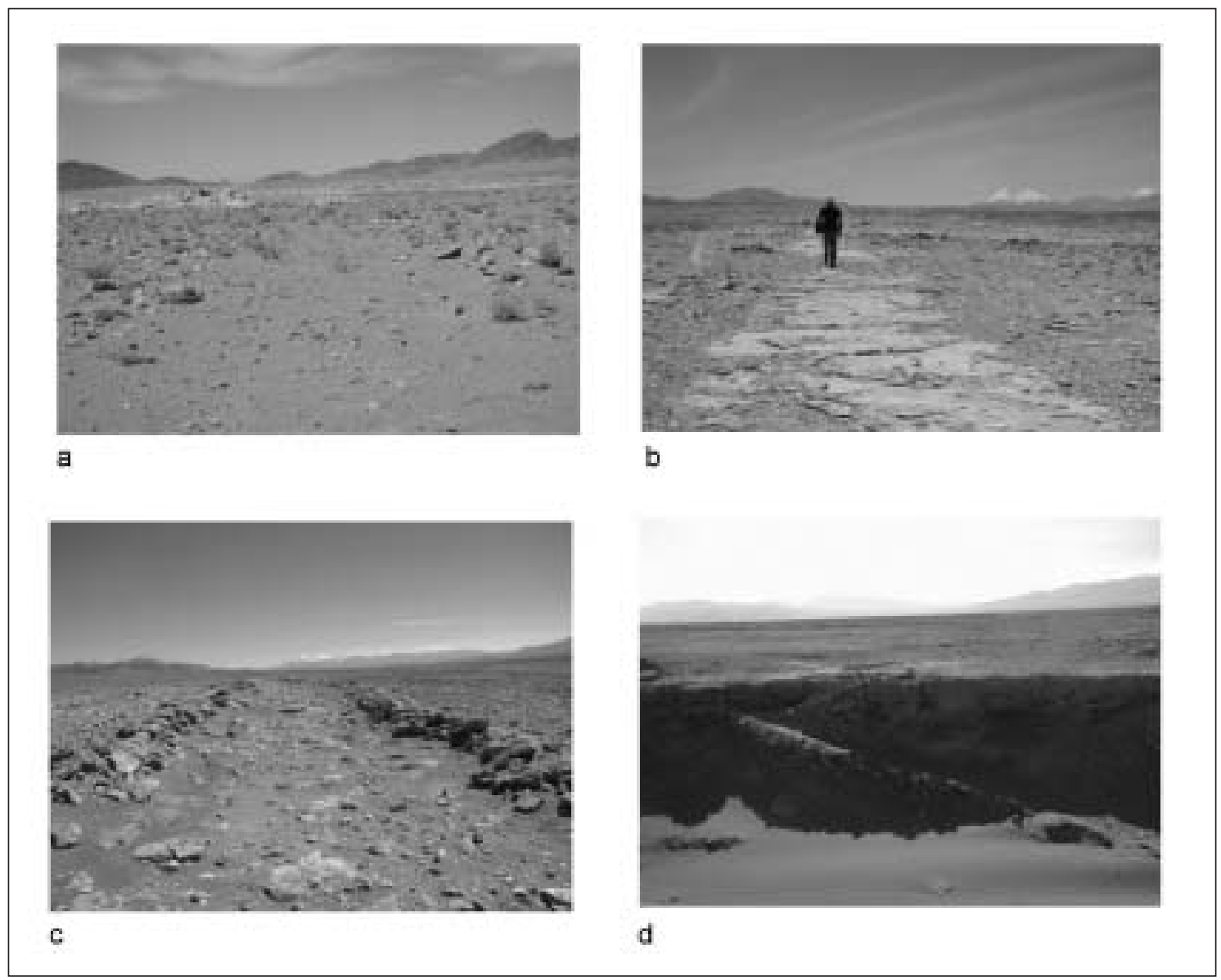

Figura 2. a) Camino inca soterrado en la arena al norte de Cerro Colorado (CG-2, Tramo 6); b) Camino inca sobre roca sólida al sur de Incaguasi (AB-11, Tramo 9); c) Camino inca sobre roca disgregada al norte de Incaguasi (CS-3, Tramo 8); d) Cuesta con muro de contención poco antes de Lasana (RP-28, Tramo 9).

les (Figura 2c). En suma, el camino inca del Alto Loa se parece mucho a los segmentos viales escasamente formalizados o de baja inversión de trabajo documentados en el "Despoblado de Atacama" (Niemeyer y Rivera 1983: 156, Foto 1; Hyslop 1984: Figs. 10.2, 10.3, 15.3; Hyslop y Rivera 1984: 39) y en las cercanías de Catarpe y el río Salado (Lynch 1995-1996: Figs. 7, 8).

Señalemos, por último, que no encontramos evidencias seguras de construcción de viaductos incaicos para salvar quebradas hondas, como sucede en otras regiones de los Andes (Hyslop 1984: 317 y ss.). Posibles excepciones -altamente dudosas, en realidad- son tres "puentes" alineados con el camino en el angosto estero Nacimiento, en Miño, dos de los cuales son rudimentarios pasos hechos con tierra y vegetación apelmazadas y un tercero construido con piedras. En cambio, registramos 13 cuestas de diversas características. Cuando las laderas de las quebradas son de suave pendiente y roca viva (p.e. OL-8), lo más usual fue acondicionar rampas diagonales, dotadas de modestos pircados a borde de quebrada para orientar la circulación. Cuando son de pendiente suave y sobre roca disgregada e inestable (p.e., RP-28), se construyeron rampas diagonales sin excavación en el declive, pero con nivelamiento de la superficie mediante material de relleno y muros de contención del lado de la quebrada (Figura 2d; Hyslop 1984: Fig. 15.18B). Otras veces trazaron angostas trochas ribeteadas con piedras que siguen las sinuosidades de la pendiente (p.e., IC-15). Finalmente, cuando las laderas son de pronunciada inclinación (p.e., NA-5), se construyeron escalinatas con peldaños o escalones labrados en la propia roca o tallados en piedras traídas de un lugar cercano (Figura 3a), incluyendo situaciones en que 


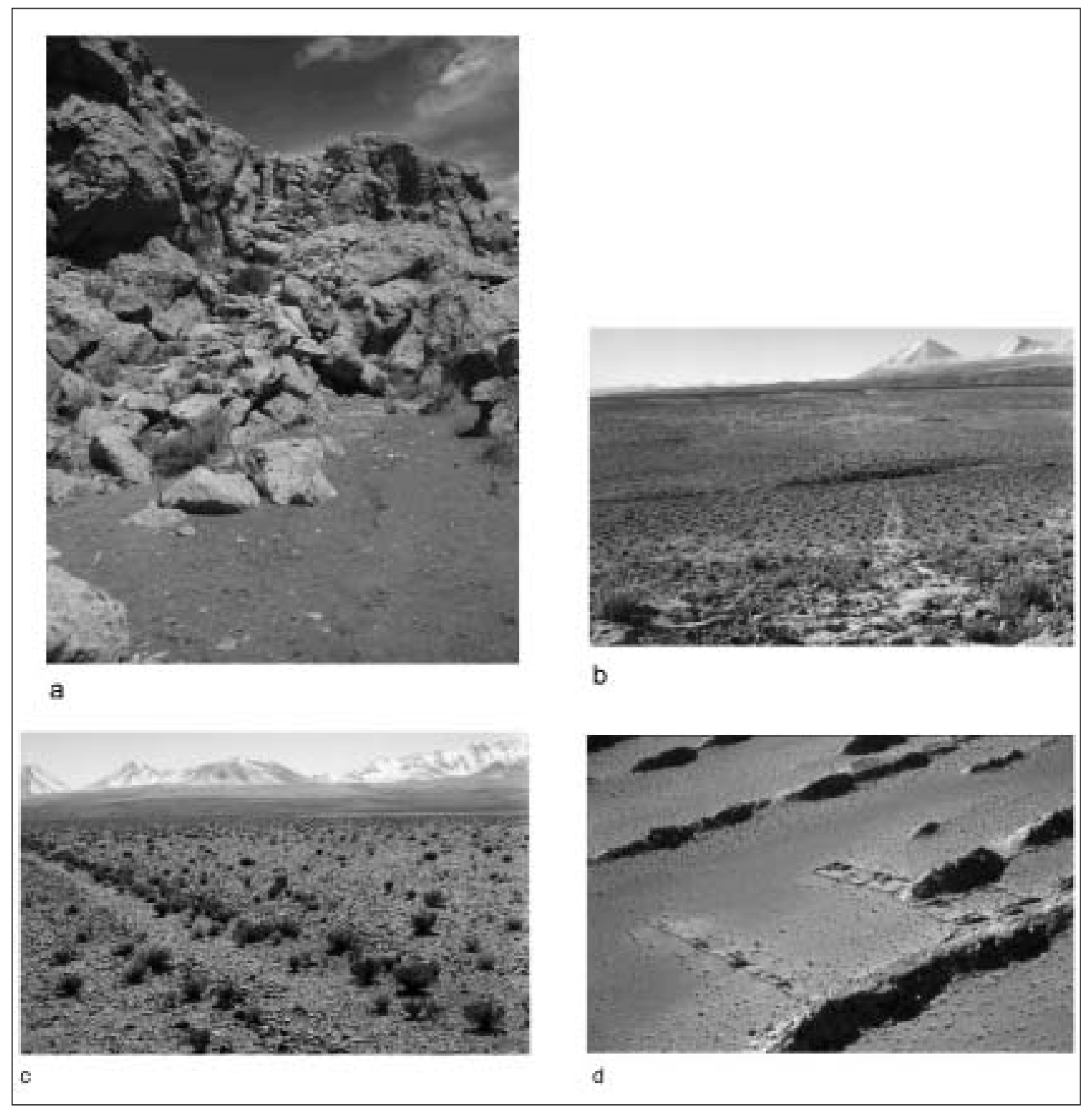

Figura 3. a) Cuesta con escalinata al sur de Bajada del Toro (Tramo 6); b) Camino al sur de Quebrada Solche (Tramo 3); c) Camino ribeteado con taras (Fabiana densa) en Pampa Tarapata (Tramo 3); d) Asentamiento inca de Cerro Colorado-1 (SBa-162, Tramo 7).

se combinan ambos procedimientos (Hyslop 1984: Fig. 15.15A).

\section{Determinantes topográficos}

Existen varias razones que explicarían por qué el camino inca discurre por la banda oriental del valle en el sector septentrional y por la occidental en el sector meridional. En el caso del primer sector, podría deberse a que el terreno es menos accidentado en las planicies orientales, ya que éstas son cruzadas por alrededor de 25 quebradas tributarias del Loa y unas 37 en las planicies opuestas. Además, por el lado oriental del valle se evitan los extensos y crispados carcanales de la banda del frente, cuya aspereza y agrietamiento son tan inhibidores para la locomoción a pie, como lo fue más tarde para el desplazamiento de vehículos rodados. De hecho, hoy los caminos de vehículos motorizados soslayan esa banda, prefiriendo el lomo de la Cordillera del Medio. En cambio la banda oriental presenta un terreno relativamente 
más grato para la marcha a pie. Además, está dotado de agua permanente en algunas quebradas y de leña y forraje a través de todo el año, lo que contrasta con el sequedal que impera en la otra banda.

En el caso del sector meridional, la topografía del terreno parece ser un factor menos relevante como explicación del derrotero del camino, pues el número de quebradas es similar en ambas bandas (cerca de 27 en la occidental y unas 30 en la oriental). Este equilibrio se extiende a la dotación de leña y forraje, incluso a la provisión de agua, ya que en ninguna de las bandas existen quebradas de escurrimiento permanente, siendo el Loa y el río San Pedro las únicas fuentes de este elemento. Un factor natural influyente, pero no determinante, para optar por el lado occidental del valle, podría ser la existencia de grandes extensiones de superficies arenosas. Como no se trata de dunas, sino de llanuras de arena bien consolidada, ofrecen menos resistencia a la marcha que las pedregosas y abrasivas superficies de detritos volcánicos que caracterizan a la banda opuesta. Con todo, creemos que el factor determinante para optar por este derrotero en el sector meridional no fue estrictamente de orden natural. Tal vez se buscó una mayor cercanía a los yacimientos cupríferos de la Cordillera del Medio. Se sabe positivamente que los minerales de Conchi Viejo, El Abra y Chuquicamata fueron explotados por los incas (Núñez 1999; Salazar 2002) y estamos estudiando evidencias de explotación cuprífera incaica en Miño, posiblemente en los yacimientos de la quebrada Conacona y vecindad inmediata.

Una de las características que más impresiona -si bien es propia del Qhapaqñan en muchas parteses la rectitud del camino a través de largos trechos. Esta no es, por supuesto, una norma invariable. En nuestro caso, el rumbo general nortesur del camino varía puntualmente al cruzar por quebradas importantes, eludir estribaciones montañosas y grandes coladas de lava, pero, una vez superado el accidente, siempre recupera su rectitud y dirección (Figura 3b).

\section{Visibilidad del camino}

El estado del camino en la actualidad es por lo general tan segmentado, que rara vez es posible seguirlo por trechos demasiado largos sin que desaparezca (Hyslop 1991: 31). Dejando de lado, por razones de espacio, la discusión del impacto antrópico, su conservación o degradación depende de varios factores naturales combinados que inciden en su visibilidad a ojo de prospector.

Uno de estos factores es la índole de la superficie por donde atraviesa. Hyslop (1991: 29) sostiene que los incas no se molestaban en construir un camino donde un sendero (en nuestros términos, una senda) era suficiente; a veces, incluso, podían conformarse con simples hitos que indicaban el recorrido. Sin embargo, creemos que éste es pocas veces el caso en el Alto Loa. La desaparición del camino o su transformación en una senda responde muchas veces a cubrimientos de la vía. Los campos de arena, en particular, actúan en ciertos sectores como genuinos "sumideros" del camino, soterrándolo a intervalos por espacio de varios kilómetros (Figura 2a). Una medida de la intensa erosión eólica de estas planicies y de sus efectos sobre construcciones incaicas, es la gran acumulación de arenas en el sitio Cerro Colorado-1 (SBa-162), al punto que muchas de sus estructuras arquitectónicas se hallan casi enteramente cubiertas por estos sedimentos. Creemos que estas condiciones dan cuenta de una parte importante de las discontinuidades o interrupciones que se observan en la arteria en estos tramos.

La roca desnuda (ignimbritas y calizas), en cambio, posibilita por lo general segmentos de visibilidad Nítida o Menos Nítida, ya que en estos costrones los elementos de la traza no se soterran ni se movilizan como ocurre en otros sustratos (Figura 2b). De ahí también que los mejores sectores para ubicar el camino incaico en terreno, sean, por lo común, las cejas de quebradas, donde la erosión ha removido la arena y otros materiales sueltos que cubren la superficie de las pampas. En las aproximaciones a las barrancas asoma roca firme o desnuda, lo que, muchas veces, permite visualizar mejor el trazado del camino que en los interfluvios.

Distinto es el caso de las zonas con detritos volcánicos cuaternarios, que suelen ofrecer visibilidades Regular y Menos que Regular. Es cierto que estos materiales imprimen un tono oscuro a las llanuras, que contrasta con la tonalidad más clara del sustrato, evidenciando de esta manera el trazado de caminos y senderos, pero esto es más factible mirando desde la altura. Este "efecto pizarra" es bastante notorio en las fotos aéreas, pero 
mucho menos acentuado cuando se está sobre el terreno. La situación es exactamente la contraria en las planchadas de ignimbritas que afloran y se alternan con las cubiertas andesíticas y basálticas, donde el camino se vuelve invisible en las fotos aéreas y sólo se hace evidente cuando se camina por la superficie.

Otro factor natural que afecta la preservación y visibilidad del camino es el tipo de drenaje prevaleciente. En el sector septentrional, las lluvias pueden alcanzar una intensidad de hasta $20 \mathrm{~mm}$ al día, cayendo sobre terrenos muy secos y de poca capacidad de absorción (IGM 1990: 50), seguramente por la impermeabilidad del sustrato de cenizas volcánicas. Como resultado, sobre los interfluvios de las planicies se originan movimientos de aguas en manto, que no se infiltran en el terreno y que tampoco son interceptadas por la vegetación. De ahí que las pampas orientales, vecinas a la más lluviosa Cordillera Andina, exhiban múltiples evidencias de "erosión de arroyada en rills" (sensu Derruau 1966: 236), las que se visualizan como una red de surcos paralelos que en ocasiones tienden a cruzarse, incluso a concentrarse, formando a veces quebradas someras. Pensamos que este tipo de erosión por el agua corriente barre los vestigios del camino, afectando de manera sustantiva su preservación arqueológica. Lo hace desmoronando hitos y moviendo de su lugar las piedras que ribetean la arteria (cuando esto no lo producen los sismos), así como borrando el lecho del camino y sus rebordes, ya sea por extracción o por depositación de sedimentos. Con todo, son estas mismas condiciones de mayor pluviosidad en el sector septentrional respecto del sector meridional, las que inciden decisivamente en situaciones como la que se observa en la Pampa Tarapata (Tramo 3, Chela IngaDesencuentro), donde alineamientos de taras (Fabiana densa) acusan el trazado del camino (Figura 3c). Probablemente, la construcción de la arteria mediante leve excavación en el sustrato de arena, cenizas y otros materiales finamente particulados que caracterizan a esta pampa, atrapa el agua en la depresión lineal durante un mayor tiempo, produciendo un crecimiento más denso y feraz de este arbusto en uno de los bordes de la vía. No obstante, es el árido medio ambiente del Tramo 9 (Incaguasi- Lasana) el que posibilita la mejor preservación y visibilidad del camino en todo el trayecto. Virtualmente carente de lluvias y con mucho menos arroyadas, en este tramo no hay casi movilización de los elementos de la tra$\mathrm{za}$, especialmente en las firmes y elevadas planchadas de calizas que asoman en ese sector cada ciertos trechos (Figuras $2 \mathrm{~b}$ y $2 \mathrm{c}$ ).

En suma, ciertas características ambientales como la litología de las penillanuras áridas del Alto Loa, así como los procesos erosivos, depositacionales y bioclimáticos que las han afectado a lo largo del tiempo, son de suma importancia para entender el trazado del camino inca y su fragmentario estado de preservación en el registro arqueológico. La alta segmentación de su traza -al punto de semejar hilvanes de diversa longitud- tiene gran parte de su explicación en estos factores naturales.

\section{Asentamientos, marcadores $\mathbf{y}$ arte rupestre}

Nuestra prospección detectó una serie de estructuras laterales que jalonan el camino inca del Alto Loa. Básicamente, consisten en 35 sitios con recintos y 63 apilamientos artificiales de piedras, ambos con una amplia variedad tipológica. En cambio, no se encontró ningún sitio de arte rupestre a lo largo de la vía o cerca de ella.

\section{Asentamientos}

Una primera categoría de sitios con recintos es aquella constituida por estructuras de planta subrectangular o cercanamente rectangular. De los 20 asentamientos menores registrados, seis caen en esta categoría. Con la sola excepción de RE-5, que está en el Tramo 2 (Esquina-Chela Inga), todos se localizan en el Tramo 9 (Incaguasi-Lasana). De los cinco asentamientos medianos, cuatro son de recintos subrectangulares (CH-1, DE-1, CG-8, $\mathrm{SBa}-163)$. Los primeros tres son de afiliación incaica en origen, pero han sido radicalmente modificados por arrieros y pastores durante los últimos 460 años. De los 11 asentamientos mayores, nueve son de recintos subrectangulares (MI1, MI-2, MI-3, NA-7, CG-9, SBa-518, SBa-162, SBa-109, LR-1) y pertenecen a diversos períodos. SBa-518 es un caserío local conectado por un desvío con CG-9, que fue ocupado durante el Período Intermedio Tardío, con una muy probable prolongación hacia el Horizonte Tardío, incluso hasta épocas posteriores al contacto. MI-1, MI-2, CG-9, SBa-162 y LR-1, en cambio, pertenecen a este último período y forman parte del sistema vial de los incas (Figuras 3d y 4a). NA-7 


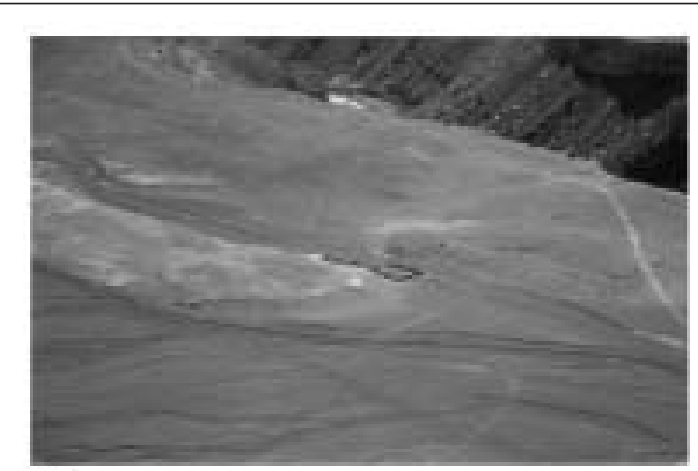

a

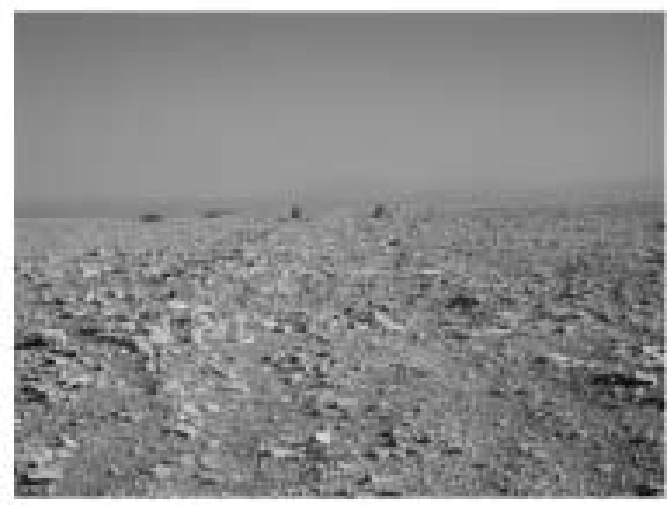

c

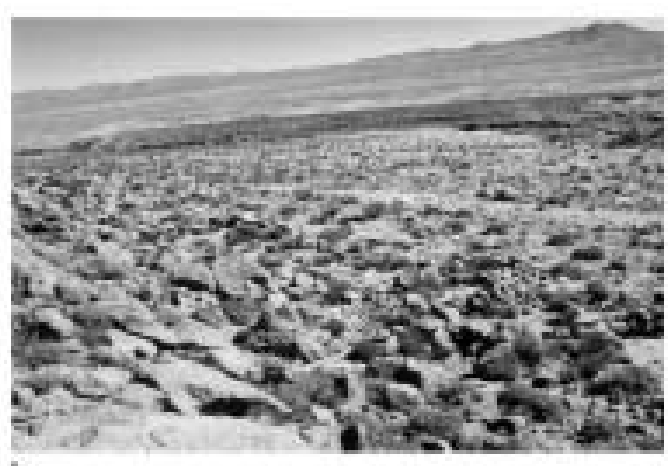

b

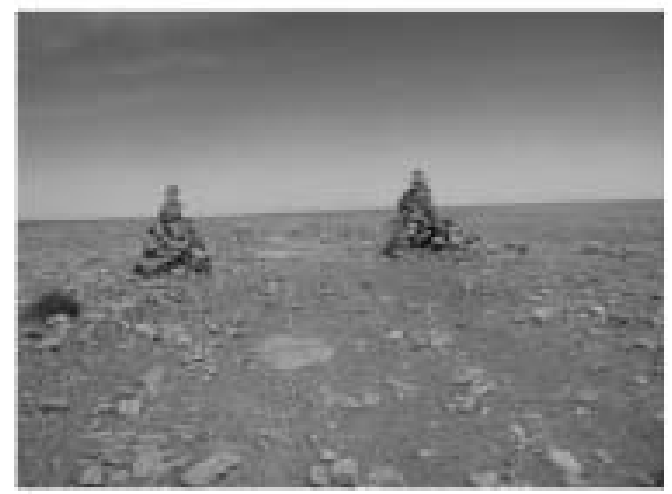

d

Figura 4. a) Asentamiento inca de Incaguasi (LR-1, Tramo 9); b) Paradero de caravanas junto a camino inca al norte de Esquina (RE7, Tramo 1); c) "Puerta" de Sandía (SV-14, Tramo 9); d) "Puerta" de Lasana (RP-17, Tramo 9).

es probablemente un asentamiento del Horizonte Tardío, severamente alterado por un asentamiento colonial y/o republicano. MI-3 y SBa-109, finalmente, son asentamientos enteramente pertenecientes al Período Colonial y/o Republicano.

Una categoría de sitios con recintos, que hace 20 años intrigó a Niemeyer y Rivera (1983: Figs. 4, 13-15, Fotos 19, 20) y a Hyslop (1984: Figs. $10.9 \mathrm{~A}, 10.10 \mathrm{~A}$ y $\mathrm{B}$ ) en sus respectivos estudios de la ruta incaica del "Despoblado de Atacama", fue aquella que este último autor denominó "categoría subcircular", formada por estructuras de planta circular, aproximadamente circular o en forma de coma. Son 22 sitios, que contienen una a 20 estructuras, localizadas a uno o ambos lados del camino inca, y que aprovechan protecciones naturales, tales como desniveles de las planchadas de ignimbritas, afloramientos rocosos o barrancas. Aunque algunas veces contienen fragmentos de cerámica inca, no exhiben características arquitectónicas incaicas y nunca aparecen combinadas con estructuras subrectangulares, exhibiendo, más bien, un aire arquitectónico local o regional (Niemeyer y Rivera 1983: 157; Hyslop 1984: 166-167; Hyslop y Rivera 1984: 38). Hyslop (1984) piensa que operaron como unidades habitacionales, ya que presentan implementos de uso diario, tales como fragmentos de cerámica, herramientas líticas, morteros, entre otros; añade, sin embargo, que sin fuentes de agua en una región con recursos tan limitados, tienen que haber sido aprovisionados desde otra parte. Niemeyer y Rivera (1983) los caracterizan como "refugios", "parapetos" o "paravientos", en tanto que Hyslop y Rivera (1984) hipotetizan que se trataría de unidades de habitación de los trabajadores que construyeron y/o mantuvieron el camino inca en esa parte de Atacama, o bien, campamentos estacionales de la gente local para la caza de aves y camélidos silvestres. 
Nuestra prospección en el Alto Loa arrojó 14 sitios asimilables a esta categoría por la forma subcircular de la planta de sus unidades, por su construcción expeditiva, por la manera en que su emplazamiento saca partido de protecciones naturales o "relieves negativos", por el número variable de estructuras dentro de un sitio (una a 40 unidades) y por su contigüidad a la arteria incaica. Varios de ellos coinciden o están en localizaciones cercanas a asentamientos incas (RE-7, OL-9, DE-4, CG-8, LR-2), pero no hay un solo caso en que se combinen estructuras de ambos tipos de sitios (Figura 4b). En nuestra opinión estos sitios, como también los del "Despoblado de Atacama", debieran interpretarse como paraderos de caravanas de llamas, análogos a las jaras y jaranas que encuentra Nielsen (1997: Fig. 2) en los circuitos de tráfico de los actuales llameros del altiplano de Lípez. Esto explicaría por qué esta clase de sitios se halla en fajas extremadamente desérticas, a lo largo de rutas de tráfico y en lugares con frecuencia distantes de las fuentes de agua. Explicaría también por qué carecen de arquitectura inca. Serían obra de caravaneros que usaron la ruta antes o después de la construcción del Qhapaqñan en la región. ${ }^{9}$

\section{Marcadores}

Otra clase de estructuras laterales o asociadas a la vía es el marcador, conocido entre los lugareños como "pinino". Por raro que parezca, según Hyslop y Rivera (1984: 39) el camino del Desierto de Atacama es la única parte de la red donde el curso de la vía se halla marcada por apilamientos de piedras (sin embargo, ver Vitry 2002; Martin 2004 Ms). Este es también el caso del camino inca del Alto Loa. Consisten en uno o más hitos construidos con piedras sin labrar, hoy en su mayoría total o parcialmente derrumbados. Registramos 63 de estos marcadores, clasificables en seis tipos:

9 Por ejemplo, en Chac Inca (590.029 E / 7.590.894 N, 4252 $\mathrm{m} . \mathrm{snm}$ ), un sitio localizado junto a un camino inca que ingresa de Chile a Bolivia con rumbo suroeste-noreste por el Portezuelo del Inca en dirección a Colcha K (Risopatrón 1911: 132-133, 1918: 159-161, 1924: 175; ver plano del asentamiento en Risopatrón 1918: 159), constatamos la presencia de estructuras subrectangulares de mampostería incaica cerca de estructuras subcirculares interpretables como paraderos de caravanas. Pese a que a ambos tipos de estructuras se encuentran adyacentes, no se observa coalescencia entre las unidades de ambos conjuntos.
1) simples apilamientos o pilas; 2) cónicos; 3) troncopiramidales; 4) alargados; 5) amorfos, y 6) con aletas.

Los hitos tipo pila son 54, suelen ser únicos, dobles o triples y por su baja altura, parecen estar hechos para divisarlos desde una distancia relativamente corta. Aparentemente, son de data más reciente que el camino inca. De hecho, hemos observado que estos rudimentarios apilamientos son una práctica de señalización que se mantiene hasta la actualidad entre los pastores del valle. Los hitos tipo cónico, troncopiramidales, alargados y amorfos, en cambio, son lo suficientemente altos como para divisarlos a mucha a distancia y suelen estar emplazados solos o en conjuntos, ya sea al borde del camino, en algún promontorio cercano, en abras o cerca de la ceja o borde superior de las quebradas. En ocasiones (Tramo 7, Cerro Colorado-Santa Bárbara), hay varios de ellos paralelos al camino (IC-0) y en otras (Tramo 9, Incaguasi-Lasana), forman hileras o alineamientos perpendiculares a la vía, con un par de ellos flanqueando los bordes de la arteria a modo de "puertas" (SV-14, RP-17). Similitudes formales y de emplazamiento respecto del camino incaico con aquellos reportados en otros trayectos de la región (Niemeyer y Rivera 1983: Fotos 10, 17, 18; Hyslop 1984: Fig. 10.2; Hyslop y Rivera 1984: 36; Lynch 1995-1996: Figs. 12-16), permitirían asignar a SV-14 al Período Inca. Véase, por lo demás, Guamán Poma (1980 [1616?]: 326-327), donde se muestran hitos camineros similares a éstos. Muy probablemente, fueron el producto de "amojonamientos" como los descritos por Garcilaso de la Vega (Libro Nono, Cap. XIII: 587591) para el camino inca en el "Despoblado de Atacama" (Niemeyer y Rivera 1983; Hyslop y Rivera 1984). Las hileras de hitos que se extienden a ambos lados de las dos "puertas" registradas entre Incaguasi y Lasana (Figuras 4c y 4d), particularmente en el caso de SV-14, podrían ser demarcaciones territoriales o fronteras provinciales, políticas, étnicas y/o rituales. Esta hipótesis ha sido elaborada y discutida en un contexto más amplio por Sanhueza (2004), imprimiendo una perspectiva etnohistórico-arqueológica y comparativa a un tópico de larga data entre los estudiosos del sistema vial de los incas, pero que, hasta la fecha, no ha sido abordado interdisciplinariamente y tampoco con profundidad de detalle. En cuanto a los hitos del tipo con aletas, son también suficientemente altos como para verlos a 
distancia, pero aparecen tanto en llanadas como en aproximaciones a quebradas e invariablemente constan de una sola unidad. Se trata de acumulaciones de piedras de forma cónica o subpiramidal. Presentan dos pircas de extensión a modo de aletas, que en planta forman un arco siempre abierto a uno de los nevados de la Cordillera Andina. La estructura proporciona cierto refugio del viento.

A riesgo de parecer obvios, es importante no confundir estos marcadores camineros con las apachetas (ver Pollard 1970: 278), ya que los primeros son el resultado de un solo evento de construcción, en cambio las segundas lo son de múltiples eventos, donde el montículo se va formando por el recurrente lanzamiento y acumulación de piedras (ver Hyslop 1984: Figs. 2.5, 11.9, 21.2 y 21.3; Vitry 2002). Hyslop (1984: 311) aborda el tema de la supuesta invención de estos montículos por los incas y dice encontrar evidencia de que al menos tres apachetas estaban funcionando en el tiempo del Imperio, pero reconoce que sus observaciones de campo son insuficientes para establecer si esta tradición antecedió al Tawantinsuyu. Por nuestra parte, no encontramos ni una sola apacheta en el camino inca del Alto Loa, con la posible excepción del hito con aletas OL-23, que presenta una situación algo ambigua. En efecto, se observa claramente que sobre él se han arrojado piedras al azar, que han ido cubriendo la estructura original. En este sentido, podría decirse que, con posterioridad a su construcción, el hito OL-23 ha experimentado un proceso de "apachetización". Hecha esta salvedad, la ausencia de apachetas en el camino del Alto Loa (como también en el camino del "Despoblado") sugiere que estos montículos ceremoniales no fueron propiamente ingredientes de la vialidad incaica. De hecho, el trayecto de camino inca que prospectamos en el altiplano de Lípez ${ }^{10}$, incorpora la ritualidad de viaje preincaica de los "sepulcros" (pozos de ofrenda de cuentas talladas en roca azul y en ceniza volcánica) en las tres abras por las que cruza, pero, al igual que el camino del Alto Loa, carece de apachetas (Berenguer y Nielsen 2003 Ms). Este camino se introduce de Chile a Bolivia por el Portezuelo del Inca. Pasa por las instalaciones incas de Laguna Ramaditas y Tambo Cañapa, dirigiéndose con rumbo $30^{\circ}$ al

10 Proyecto FONDECYT 7010327 de Incentivo a la Cooperación Internacional. salar de Uyuni a través del Callejón Cañapa, Laguna Pampa, el río Pucara, la Pampa Río Potrero y el Abra de Tokhari K'asa, hasta arribar a la península de Colcha K. En cambio el camino histórico que cruzaba la cordillera por el Paso de Ascotán y enlazaba el Puerto de Cobija con Potosí (Hito LXX-Laguna Ramaditas-río Tapaquilchas-Cuatro Mojones-Vizcachillas-Alota), sí presenta apachetas. Esto sugiere que la ritualidad de viaje, tanto en el Período Intermedio Tardío, como en el Horizonte Tardío, se focalizaba en los "sepulcros", en cambio la práctica relacionada con el culto de la apacheta ingresaría a esta región con posterioridad al contacto hispano (Berenguer y Nielsen 2003 Ms). En otras palabras, los datos del Alto Loa, de Lípez $\mathrm{y}$, eventualmente, del "Despoblado", clarifican tentativamente la interrogante planteada por Hyslop (1984: 311): podría ser que estos montículos ceremoniales no sean anteriores a los incas y tampoco una invención incaica, sino que correspondan a una ritualidad de viaje posterior al Tawantinsuyu.

\section{Contactos con otros tipos de vías}

Existen varias vías de distintas naturaleza y épocas que "interactúan" de diversas formas con el trazado del camino inca a lo largo de la ruta del Alto Loa.

\section{Sendas}

En varios trechos de los tramos 1 (Miño-Esquina), 2 (Esquina-Chela Inga), 3 (Chela IngaDesencuentro) y 5 (Lequena Viejo-Bajada del Toro), el camino inca se transforma en una angosta senda de 30 a $40 \mathrm{~cm}$ de ancho, particularmente cuando discurre sobre arena. Nuestra interpretación de esos casos es que el camino ha sido borrado por la erosión y que la senda es el producto del trajín de caminantes posteriores al Horizonte Tardío (Figura 5a). Otra situación son las sendas igualmente angostas que cruzan la arteria en numerosos puntos. Se trata en estos casos de un tráfico que, obviamente, no utiliza la arteria y que se efectúa para conectar ciertos lugares dentro de una determinada localidad. Los puntos donde se producen intersecciones muestran claramente que estas sendas vecinales pasan sobre el camino, de manera que también son el producto de caminantes posteriores a los incas. En ningún lugar del trayecto Miño-Lasana encontramos "contactos" entre la vía inca y sendas que sean convincentemente preincaicas o incaicas. 


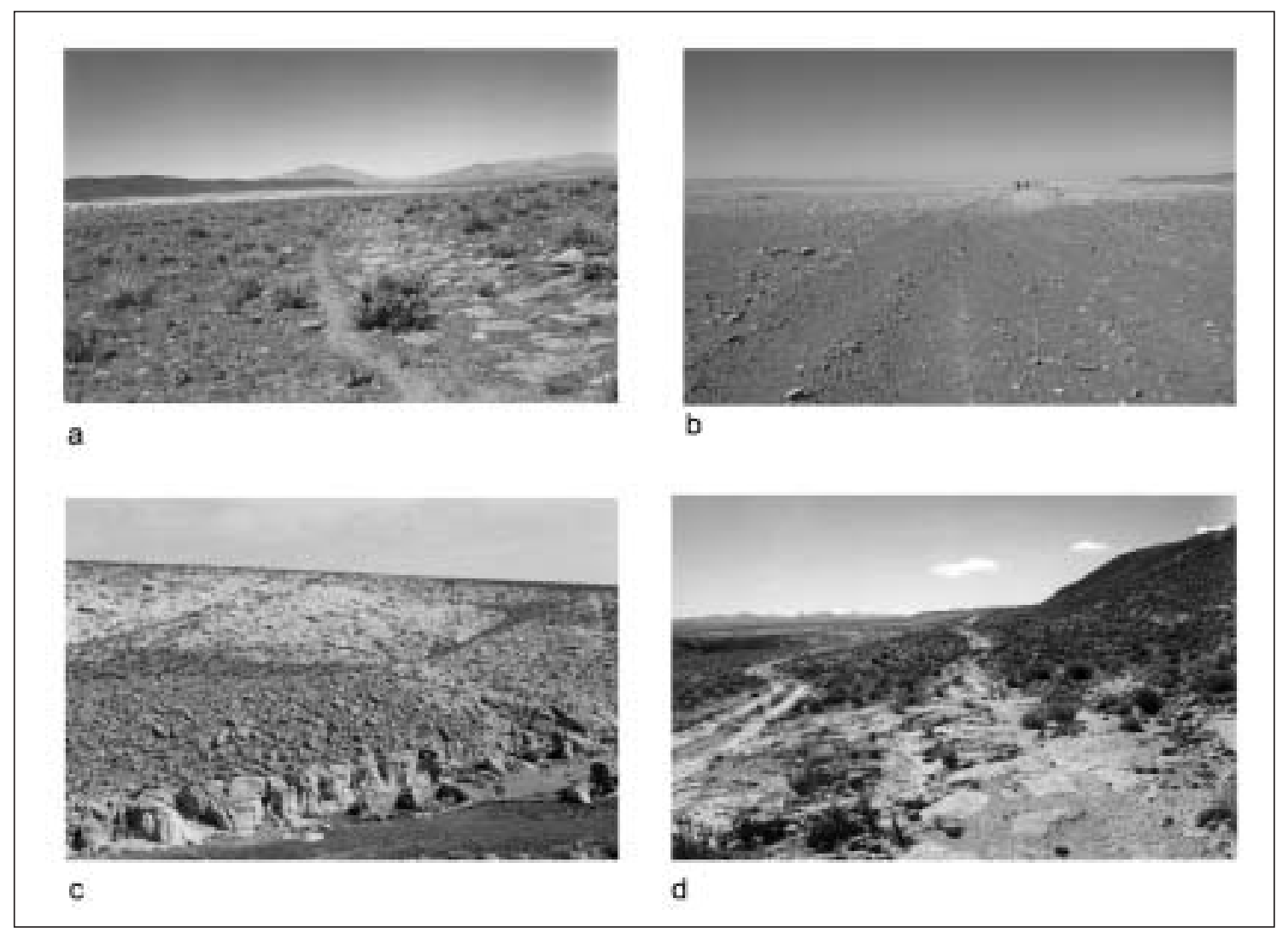

Figura 5. a) Senda sobre camino inca en Solche (TA-5, Tramo 3); b) Sendero tropero en primer plano y camino inca al fondo en Sandía (SV-4, Tramo 9); c) Rampa de sendero tropero (superior) y de camino inca (inferior) en río Chela (CH-1, Tramo 3); d) Camino de carreta (izquierda) y camino inca (derecha) al sur de Esquina (Tramo 2).

\section{Senderos troperos}

La situación de los senderos troperos es más compleja. De todas las vías distintas al camino inca, este tipo es el que "interactúa" en forma más frecuente y variada con él, sugiriendo que hubo cierta identificación entre ambas lógicas de tráfico (Figura 5b). En ocasiones, sus surcos paralelos ("rastrillados") o entrelazados ("trenzados") siguen el derrotero del camino inca a cierta distancia, pero a veces lo cruzan (p.e., SV-3, -4) o se le superponen (p.e., SV-1). Naturalmente, estos dos últimos casos tienen consecuencias sobre la integridad de la arteria, ya que destruyen sus bordes u obliteran su traza, a veces por largos trechos. Por otra parte, es suficientemente claro que -pese a frecuentes divagaciones laterales- los senderos troperos tienden a seguir muy cercanamente el derrotero del camino en las zonas de interfluvio, pero al arribar a una quebrada importante, característicamente eluden las empinadas cuestas incaicas, cru- zándola por lugares diferentes aunque relativamente cercanos. En el cruce del río Chela, por ejemplo, el sendero tropero hace uno de estos pequeños rodeos (Figura 5c). Es también claro que muchas veces los senderos troperos se apartan de la vía incaica cuando ésta pasa por carcanales y afloramientos de calizas, como si procurasen evitar terrenos de roca sólida. En otras palabras, mientras los senderos tienden a soslayar accidentes topográficos y ciertas superficies, el camino inca corta a través de ellos. Por otra parte, la posibilidad de que estos senderos sean fruto de un tráfico con caravanas de llamas es altamente factible, pero debe evaluarse con prudencia. Aunque en la región la llama se empleó como la principal bestia de carga hasta bien avanzado el siglo XVII, desde entonces fue rápida, si bien no totalmente, sustituida por la mula (Sanhueza 1991). Por tratarse de animales pesados, dotados de cascos y provistos de herraduras, el impacto de estos equinos sobre la traza del camino es mucho más 
destructivo que las acolchadas patas de las llamas o que el calzado de simples peatones (Lynch 19951996). Frente a esto, sin embargo, se mantiene firme la evidencia de numerosos senderos troperos incuestionablemente preincaicos, especialmente en torno a la Rinconada de Santa Bárbara (Berenguer 2004a: 304-332, Figs. 6.1, 6.2, 6.5, 6.7c, 6.11). Volveremos sobre este punto al final del artículo, al referirnos a la cronología.

\section{Caminos de carretas}

Los caminos de carretas, por último, presentan una situación muy distinta a las sendas, senderos y caminos incas. Claramente su trazado responde a otras exigencias de tráfico. Por tratarse de vehículos rodados, por lo general suelen desviarse considerablemente de su trayectoria general, especialmente cuando deben superar quebradas muy hondas y de laderas demasiado empinadas. Tanto así, que sus trazados son fácilmente reconocibles en las fotos aéreas. Típicamente, hacen un largo rodeo, cruzando por cotas más altas que los senderos troperos y la arteria incaica, especialmente donde las quebradas son menos profundas. Sus grandes ruedas, provistas de huinchas de acero (véase ejemplares de estas carretas en el acceso al Pucara de Lasana y en la vecina localidad de Pona), son las responsables de los profundos surcos paralelos que aparecen en las zonas donde aflora roca firme. Estos segmentos de caminos carreteros tienen un ancho promedio similar al del camino inca (aprox. $4 \mathrm{~m}$ ), nunca obliteran esta vía y rara vez corren paralelos a ella (Figura 5d). Sólo constatamos unas pocas intersecciones, particularmente al sur de Esquina y cerca de Desencuentro, donde ambos viales concurren, en el primer caso por el angostamiento de la planicie y en el segundo, seguramente para aprovechar el vado que existe en el lugar. En otras palabras, las huellas de carretas difícilmente se pueden confundir con el camino inca.

\section{Continuaciones, variantes y enlaces}

\section{Conexión con Collaguasi}

En Miño, el camino que pasa por MI-2 (Kona Kona-2) proviene del norte. Lo que no sabemos es si, en algún punto aguas arriba de este lugar, ocurre una confluencia entre el eje vial que procede de Tarapacá (Santoro 1982) y el referido por Le Paige (1958) como bajando a Miño desde Ujina o se trata de la misma arteria. Este es un proble- ma que sólo podremos dilucidar en otra investigación. Sea como sea, la arteria de Ujina es la más probable conexión entre el camino inca del Alto Loa y el que pasa por el antiguo Complejo Minero de Collaguasi (Lynch y Núñez 1994), un yacimiento que fue explotado en tiempos preincaicos, incaicos, coloniales y republicanos tempranos (Núñez 1999: 185). Según este último autor, esta localidad presenta

"grandes corrales y abundantes bodegas, en parte relacionadas con el recurso minero de Collaguasi, agregándose como el locus metalífero intermedio o número once a los diez descritos por Raffino (1981), básicamente entre las evidencias del valle de Camarones y el Loa Superior" (Núñez 1999: 186; ver también Romero y Briones 1999).

\section{Conexión con El Abra y Conchi Viejo}

La relevancia de los hallazgos incaicos en el Complejo Minero San José del Abra (Núñez 1999; Salazar 2002), ya ha sido oportunamente resaltada y no es necesario repetirla aquí. Baste señalar que es el más importante yacimiento cuprífero explotado por los incas en el valle y tal vez en la región. De ahí que sea crucial encontrar las vías que conectaron al camino del Alto Loa con los campamentos mineros del yacimiento (Berenguer 2004a: 311). Después de todo, Salazar (2002) postula la existencia de un importante "tambo" en Conchi Viejo, a medio camino entre El Abra y el cañón del Loa. Este lugar está casi equidistante de los sitios Cerro Colorado-1 (SBa-162) e Incaguasi (LR-1) y desde hace mucho se conocen los hallazgos de Latcham (1928: 112, 118, Fig. 69) en un cementerio de ese lugar, que incluyen un aríbalo y otras vasijas presumiblemente incaicas, acompañadas de piezas locales (Berenguer 2004a: 230).

Desgraciadamente, nuestros esfuerzos por encontrar una conexión han sido hasta ahora infructuosos. Por ejemplo, al sur de Lequena Viejo (NA7), al abrirse la extensa Pampa Cerrillos, podría desprenderse del camino inca una variante hacia el suroeste que pase al poniente del cordón Cerro Colorado para dirigirse a Conchi Viejo y El Abra, pero no logramos visualizar una bifurcación en terreno. Un reciente reconocimiento ${ }^{11}$ del sector

11 Realizado en vehículo junto a D. Salazar. 
situado entre los cerros Colorado y Pajonal, practicado para evaluar esta posibilidad, no ofreció evidencias, aunque sólo recorrimos el lado oriental de la quebrada y únicamente hasta el punto denominado Abra de Justo. Por otra parte, al pie de la ladera sur del Abra de Revinco, como también al sur y oeste de Cerro Guacho, nuevamente hay condiciones topográficas para que se desprendan una variante de la arteria troncal que conduzca a Conchi Viejo y El Abra. De hecho, Le Paige (1958: 79; ver también Varela 1999: Fig. 1) hipotetiza un derrotero que podría calzar con estas localizaciones. No obstante, tampoco pudimos visualizarlas. De ahí que sea válida la pregunta de si, necesariamente, estas variantes de conexión del camino inca con los yacimientos tuvieron un trazado de construcción formal, o más bien, fueron sencillos senderos troperos (D. Salazar, com. pers. 2004). Más al sur, en todo caso, los datos son algo más alentadores. Previsualizaciones de rasgos lineales en fotografías aéreas, sugieren que una variante proveniente de Conchi Viejo y El Abra conecta con el camino inca en algún punto cercano al Cerro Añil (ver fotogramas SAF CH30 S.4-5: $n^{\circ} 022712,022713$ y 022714). Le Paige (1958) plantea vagamente esta posibilidad, la que es recogida en el mapa de Varela (1999: Fig. 1) y comentada por Salazar (2002). El último de estos fotogramas muestra muy claramente que el segmento de camino detectado al norte de Incaguasi (CS-2, 3, 5, 7), proviene de los faldeos orientales del Cerro Añil, aunque es cruzado por la línea del ferrocarril Antofagasta-Bolivia y por la carretera a El Abra. Razones de seguridad (el terreno exhibe letreros advirtiendo la existencia de explosivos) impidieron la verificación de esta hipótesis vial en terreno.

\section{Conexión con la zona norte de Lípez}

La ruta a través del Portezuelo de Ascotán, ha sido siempre para nosotros una buena candidata para encontrar una conexión con la zona norte del altiplano de Lípez. En particular, identificar una vía que partiendo del camino inca del Alto Loa, atraviese el salar de Ascotán y el Portezuelo del Inca hasta enlazar con el ramal incaico que detectamos al otro lado de la frontera con Bolivia (Berenguer y Nielsen 2003 Ms). Sabemos que por allí pasaron los senderos troperos que en el Período Intermedio Tardío unían a Lasana-Chiu Chiu con el altiplano (Berenguer 2004a) y también la ruta histórica que conectaba la costa del Pacífico con la región de Lípez y el altiplano de Potosí (SBa-203; Berenguer 2004a: Fig. 6.2). Efectivamente, durante el Período Colonial una de las principales vías de articulación de la antigua Atacama con el Alto Perú era aquella que comunicaba el enclave de Cobija con el Loa, siguiendo su curso hasta la localidad de Santa Bárbara, desde donde enfilaba hacia el altiplano de Lípez a través de Ascotán. La ruta continuaba por Tapaquilchas (donde comenzaba la jurisdicción de Lípez), Vizcachillas, Alota, Río Grande (en las cercanías de San Cristóbal) y de allí hacia los centros mineros y urbanos de Porco y Potosí (Cañete y Domínguez 1974 [1797]). Durante el sigloXIX, ésta continuó siendo la ruta principal de comunicación con el interior de Bolivia, y su utilización se vio incrementada con la instauración oficial del sistema de "postas" o "tambos" (Cajías 1975).

Conexión con la zona sur de Lípez y el Alto Salado

Cabe la posibilidad que, del camino inca que baja a la quebrada del Loa al norte de la Quebrada Quinchamale (IC-13), se desprenda un enlace hacia el oriente. Hipotéticamente, subiría por la cuesta que pasa por el caserío SBa-119 y se dirigiría a través del sendero SBa-202 (Berenguer 2004a: 309) hacia las arterias altiplánicas o hacia la que pasa por Inacaliri y la cuenca alta del río Salado (Varela 1999: 103). Aunque todavía no hemos explorado en terreno esta posibilidad con una "hipótesis incaica" en mente, está dentro de nuestros planes inmediatos.

\section{Conexión con Chiu Chiu}

De modo similar a como sucede en Miño, no hay duda que el camino inca que pasa por los altos de Lasana continúa hacia Chiu Chiu. En nuestra prospección, sin embargo, logramos reconocer segmentos de esta vía únicamente hasta poco más al sur del ducto de agua que atraviesa el valle a la altura de Lasana, después de lo cual desaparece, obliterada por múltiples vías de tráfico de diferente naturaleza y época imprecisable. En consecuencia, ignoramos si poco más adelante la arteria incaica desciende por el cañón y continúa por el piso del valle hasta el oasis de Chiu Chiu, o bien, discurre por la planicie superior, para des- 
cender a este poblado sólo una vez que el cañón desaparece, aguas abajo del sector Chacras Viejas. Lo más probable es que la vía haya continuado al sur por la planicie superior, para evitar que los animales de carga que transitaban por ella pasasen por los campos de cultivos del valle de Lasana, bajando al mencionado oasis frente al asentamiento conocido como "Pucara de Chiu Chiu" o, más probablemente, en el punto donde están las ruinas conocidas como "Chiu Chiu Viejo", un centenar de metros al sur del puente que conduce al pueblo actual.

\section{Sumario y consideraciones finales}

Desde MI-2 en Miño (536023 E / 7659621 N, $3932 \mathrm{~m} . \mathrm{snm}$ ) hasta RP-29 en Lasana (537950 E / $7537707 \mathrm{~N}, 2677$ m.snm), nuestra prospección arqueológica del Alto Loa cubrió 125.07 km lineales y un desnivel de $1255 \mathrm{~m}$. Los datos duros provienen de cuatro expediciones efectuadas entre 2001 y 2003 , en que se registraron 285 puntos de interés, e incluyen nueve tramos, irregularmente espaciados de norte a sur $(16.06 \mathrm{~km} ; 8.01 \mathrm{~km}$; $22.93 \mathrm{~km} ; 11.73 \mathrm{~km} ; 10.15 \mathrm{~km} ; 7.78 \mathrm{~km} ; 11.5$ $\mathrm{km} ; 17.93 \mathrm{~km}$ y $17.53 \mathrm{~km}$, respectivamente); 44 segmentos de camino de visibilidad Nítida, 51 Menos Nítida, 59 segmentos Regular, 40 Menos que Regular y 95 Invisibles; tres posibles puentes; 13 cuestas; un ancho promedio de $4 \mathrm{~m} ; 20$ asentamientos menores, cuatro asentamientos medianos y 11 asentamientos mayores, y 54 hitos simples y nueve complejos.

Respecto a las interrogantes enunciadas al comienzo del artículo, nuestro estudio micromorfológico de la ruta del Alto Loa ha generado nuevo conocimiento acerca de la vialidad inca, específicamente en siete aspectos que hasta ahora permanecían como vacíos de información o como puntos controvertidos:

1) Comprobamos sobre el terreno la existencia del camino incaico, tantas veces referido por diversas fuentes, pero nunca investigado en forma sistemática. En el curso de esta tarea, mapeamos y establecimos detalladamente su derrotero, ratificando en algunos casos lo señalado en las publicaciones y corrigiéndolo en otros. Además, comprobamos la existencia de dos desvíos (a Bajada del Toro y al Pucara de Lasana) e hipotetizamos un tercero (al Cerro Cirahue).
2) Describimos en detalle las características constructivas de la arteria y las cotejamos con las de otros trayectos del desierto, aportando -con los caminos por depresionamientos en arena- un nuevo caso, que, hasta donde sabemos, enriquece el espectro de formas constructivas del Qhapaqñan.

3) Discutimos los determinantes topográficos del trazado del camino, procurando explicar por qué corre por donde lo hace, cuestión que rara vez se aborda en esta clase de estudios.

4) Analizamos factores postdepositacionales naturales que influyen en su preservación y, en último término, en su visibilidad a ojo de prospector, un aspecto tocado pero no suficientemente analizado por Hyslop (1984) y generalmente obviado por otros investigadores. Con esto hacemos una contribución metodológica para futuras investigaciones sobre el sistema vial de los incas, especialmente en ambientes áridos y semiáridos.

5) Describimos, clasificamos y evaluamos la pertenencia a los incas (o a otros grupos o épocas) de diferentes clases de sitios y rasgos localizados a la vera del Qhapaqñan, incluyendo sitios de recintos subrectangulares y subcirculares, así como diferentes tipos de marcadores camineros.

6) Comprobamos que no existen sitios de arte rupestre a lo largo del camino o en localizaciones inmediatamente contiguas a éste. Más adelante comentamos en forma más amplia este resultado "negativo".

7) Describimos y analizamos zonas de contacto y de adyacencia entre la arteria inca y otras vías de circulación, proporcionando una inédita perspectiva procesual en la región sobre diferentes sistemas viales. Como resultado, demostramos que el camino inca hizo uso de rutas caravaneras preincaicas y que el camino, pero principalmente la ruta, siguió empleándose a trechos durante los períodos Tardío, Colonial y Republicano.

Por otra parte, nuestro análisis macromorfológico permitió esbozar la extensión de la red vial inca dentro del Alto Loa y más allá de este valle, hipotetizando continuaciones y ramales que conectan a la arteria del Alto Loa con puntos clave dentro de la economía del Tawantinsuyu, así como con otros ejes viales del Qhapaqñan, contribuyendo a avizorar cuál era la configuración global de 
la red incaica en el cuadrante noreste de la Región de Antofagasta. Este análisis requiere, por supuesto, mayor verificación en terreno y debiera ser parte importante de las próximas investigaciones en el área. En particular, debiera prospectarse la proyección o continuación del camino hacia Collaguasi en el norte. Igualmente, debieran buscarse posibles variantes, quizás más sencillas, hacia Conchi Viejo y El Abra en el oeste, como también posibles enlaces con el altiplano de Lípez y el Alto Salado en el este.

Hay varias reflexiones, proposiciones y proyecciones de la investigación que surgen de estos resultados y que son de importancia para la prehistoria de la Región de Antofagasta.

1) Respecto de la cronología de los ejes viales del Alto Loa (senderos, troperos, camino inca y caminos coloniales), el escaso, pero indicativo hallazgo de cerámicas Los Morros, Vaquerías y Negro Pulido Clásico en torno a la vía incaica, señala que la ruta (no el camino) fue transitada al menos desde el Formativo Medio y Tardío. Otro bloque temporal, esta vez más fuertemente representado que el anterior, es el Período Intermedio Tardío, a través de la cerámica Ayquina, Dupont, Turi Gris Alisado, Turi Rojo Alisado, Turi Rojo Burdo, Turi Rojo Pulido, Turi Rojo Revestido, Charcollo, Chilpe y Hedionda (Uribe y Cabello 2004 Ms). Estos dos cuerpos de datos cerámicos señalan claramente que, al igual que en el "Despoblado de Atacama" (Niemeyer y Rivera 1983), la ruta por la que se trazó el camino inca en el Alto Loa no era prístina, sino secundaria, de manera que está abierta la posibilidad de que algunos senderos troperos sean de data preincaica. Varios senderos y paraderos de caravanas ejemplifican esta situación, pero su fundamentación escapa a los objetivos del presente trabajo. El camino, en cambio, es de construcción netamente inca y fue usado durante ese período, como lo comprueba no sólo la arquitectura de varios asentamientos, sino también el hallazgo de cerámica importada o local relacionada con los incas (Uribe y Cabello $2004 \mathrm{Ms}$ ), tales como Turi Rojo Pulido, Turi Rojo Revestido Exterior/Negro Alisado Interior, Lasana Café Rojizo Pulido Exterior, Lasana Café Rojizo Pulido Ambas Caras, Inka, Diaguita, Saxamar y Yavi (Figuras 6 y 7). Una batería de 11 dataciones radiocarbónicas y 20 termoluminiscentes ( 21 de las cuales caen en- tre 1400 y 1600 DC) apoyan en forma independiente la discriminación de estos bloques temporales.

Por otra parte y siempre en este mismo sentido, nuestro estudio de las "zonas de contacto" entre la vialidad tropera y la incaica muestra que, en varios casos, corresponden a un tráfico posterior al Período Inca. Documentos de los siglos XVIII y XIX indican la utilización del Alto Loa como ruta de correos colonial, como ruta militar para abastecer a las tropas, como ruta ganadera hacia las tierras bajas y principalmente como ruta minera (Magallanes 1912; Boletín de la Guerra del Pacífico 1979: 115; Risopatrón 1911). A este tráfico responde seguramente el hallazgo de cerámica Turi Café Alisado y Santa Bárbara Rojo Burdo, así como de loza, vidrio y otros artefactos posteriores al período de contacto. En síntesis, no hay duda de que el camino inca del Alto Loa se construyó sobre una ruta de tráfico preexistente (Hyslop 1992; Mostny 1949; Nielsen 1997 Ms), proceso en el cual se adoptaron, racionalizaron y formalizaron, en algunos casos, antiguos senderos caravaneros, pero tampoco hay dudas de que el camino (y la ruta en general) siguió usándose por el tráfico tropero y arriero con posterioridad al Tawantinsuyu.

2) Desde Desencuentro al norte (sector septentrional), es posible que el camino inca del Alto Loa sea, en gran parte, una vía de conexión o de entronque entre dos diferentes áreas de la ocupación incaica en el valle. Los fundamentos de esta aseveración son principalmente cuatro: en contraste con el sector meridional, esta vía: a) atraviesa áreas virtualmente despobladas; b) los hitos o marcadores camineros son más escasos, tipológicamente menos diversos y constructivamente más sencillos; c) las instalaciones incaicas son menos numerosas y, con la sola excepción de MI-1 y MI-2, son de menor tamaño y más simples, y d) el hallazgo de cerámica atacameña es menor y el hallazgo de cerámica tarapaqueña es algo mayor.

Desde Desencuentro al sur (sector meridional), por otra parte, no hay razones topográficas, de naturaleza de la superficie o de provisión de agua, leña $\mathrm{y}$ forraje que hayan forzado a trazar el camino por la banda occidental. Es más, en el Tramo 7 (Cerro Colorado-Santa Bárbara) el espolón formado por los cerros Blanco, Abra de Revinco y 


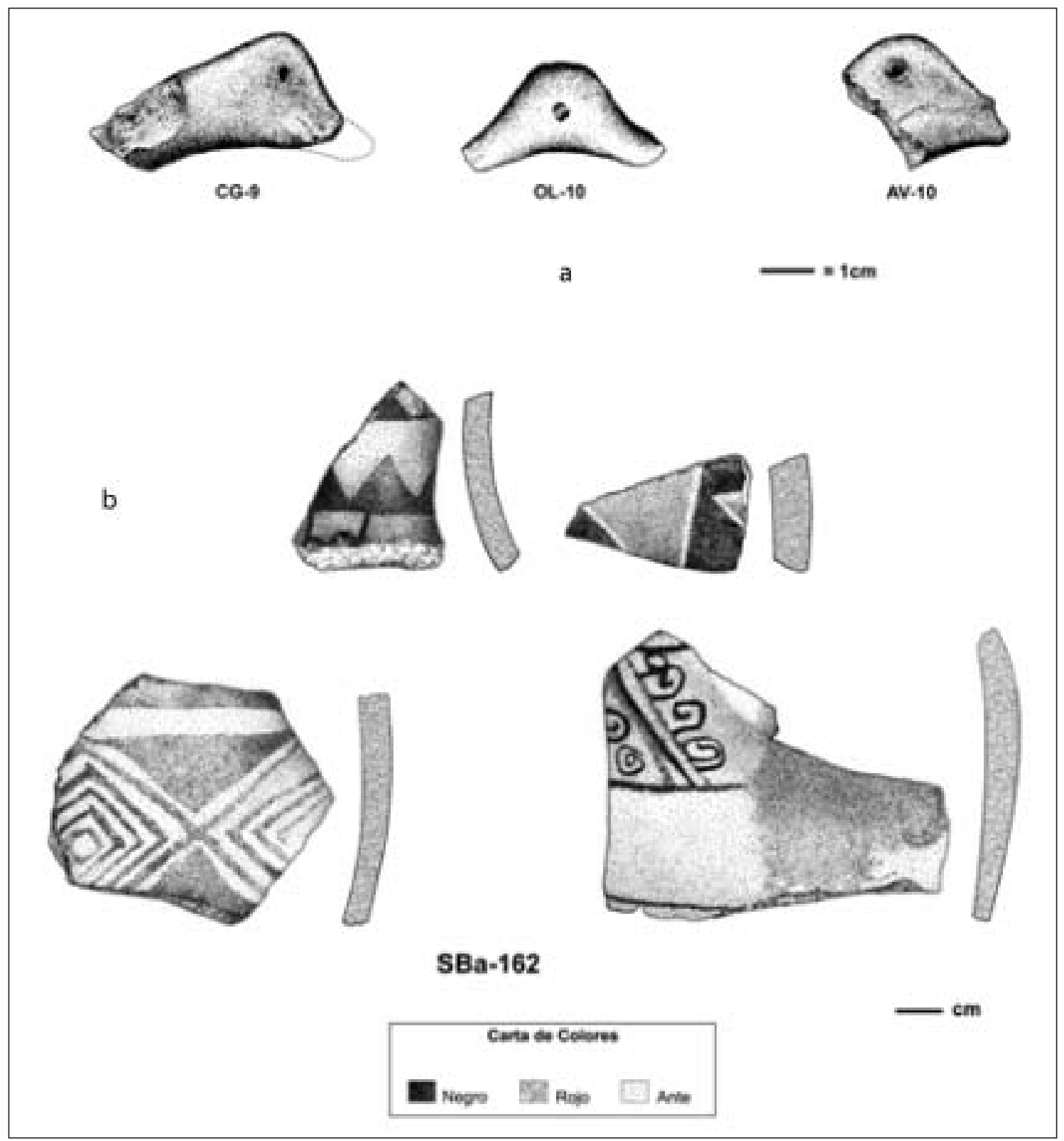

Figura 6. Cerámica incaica encontrada en el camino y en asentamientos laterales: a) Fragmentos de platos ornitomorfos tipo Rojo Revestido Pulido Ambas Caras (TPA); b) Fragmentos de aríbalos tipo Inca Cusco Policromo (INK).

Las Papas, es una barrera que obliga a desviar profundamente hacia el oeste el rumbo del camino y a superar una empinada cuesta, cosa que no ocurre en la banda opuesta. Nos asiste la convicción de que el determinante de este derrotero es la localización de yacimientos cupríferos en la Cordillera del Medio, particularmente, El Abra y Conchi Viejo.
3) La reflexión anterior permite discutir -si bien no dilucidar- un punto que es central dentro de la problemática sobre los intereses económicos de los incas en la región. Mientras Llagostera (1976; ver también Salazar 2002) postula que la ocupación incaica tuvo una orientación agrominera y Uribe y Carrasco (1999) sostienen que fue una orientación más minera que agrícola, Núñez (1999) defiende la idea de que lo que en realidad 


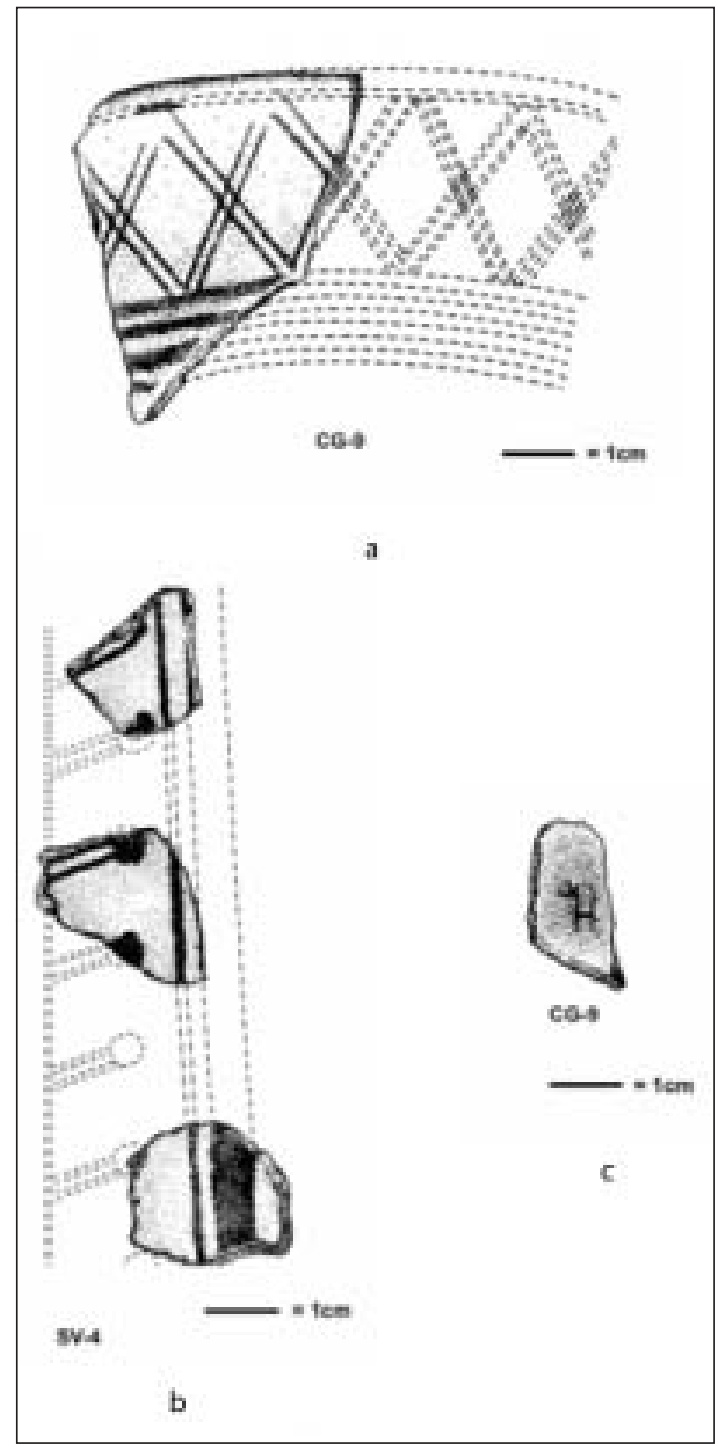

Figura 7. Cerámica incaica encontrada en el camino y en asentamientos laterales: a) Fragmento de escudilla tipo Inca Cusco Policromo (INK); b) Fragmento de aríbalo decorado tipo Lasana Café Rojizo Revestido Exterior (LCE); c) Fragmento de escudilla decorada tipo Saxamar o Inca Pacajes (SAX).

atrajo a los incas fueron los minerales. El trazado del Qhapaqñan en el Alto Loa por la banda occidental favorece fuertemente esta última posición. Aunque todavía no hemos podido detectar los ramales que conectan los yacimientos con la vía troncal, es evidente que ésta discurre alineada con el eje norte-sur de la Cordillera del Medio. Probablemente el trazado va haciendo un compromiso entre la distancia a los recursos de esa cordillera y la distancia a los recursos del valle. Con estos antecedentes, sería conveniente abandonar el tratamiento del tema en términos de "orientaciones económicas" prevalecientes, ya que este enfoque pareciera haber agotado su vida útil y no tener mucho valor heurístico. Proponemos focalizarlo, más bien, en la discusión sobre los recursos que primariamente atrajeron a los incas en la región. Así, es posible enfatizar que la motivación fue minera, ya sea enfocada en la metalurgia (Núñez 1999), en la lapidaria (Salazar 2002) o en ambas, y que la agricultura (y el pastoreo) fueron actividades de apoyo a los contingentes mineros y caravaneros. En este sentido, la vía troncal y sus ramales servirían necesidades de comunicación, transporte y apoyo logístico para la explotación de recursos mineros valiosos.

4) El número, tamaño, complejidad y localización de las instalaciones incaicas asociadas al camino inca del Alto Loa, permiten hipotetizar sistemas de sitios laterales, organizados en tres niveles jerárquicos: sitios primarios, destinados a actividades administrativas; sitios secundarios, consagrados a alojamiento, abastecimiento y control del movimiento de personas y animales; y sitios terciarios, orientados a proveer refugio a los viajeros. En este modelo, el sistema del sector meridional estaría conformado por Cerro Colorado-1 (SBa-62) como sitio primario; Desencuentro (DE1), Bajada del Toro (CG-9), Santa Bárbara (SBa109?) e Incaguasi (LR-1) como sitios secundarios; y múltiples estructuras unirrecintuales como sitios terciarios. El sistema del sector septentrional, en cambio, se halla más débilmente documentado. Estaría conformado por MI-1 y MI-2, como sitios primarios; Chela Inga ( $\mathrm{CH}-1)$ como sitio secundario; y Esquina (RE-5) como sitio terciario. Este escenario, por supuesto, cuestionaría a Esquina como cabecera de tramo, quedando el trecho Miño y Chela Inga como un solo tramo. En todo caso, si el modelo referido es correcto y generalizable más allá del Alto Loa, y si el sistema anticipado para el sector meridional tiene asidero en la realidad, sería esperable encontrar otros sitios secundarios y terciarios entre Miño y el siguiente sitio primario hacia el norte.

5) Está bien establecido que la riqueza del Imperio Inca se basaba no sólo en la explotación de recursos naturales de alto valor social y económico, sino también en el acceso a mano de obra (Murra 1978 [1955]). El sistema vial incaico estaba en gran parte destinado a la obtención, administración, movilización y protección de estos 
contingentes (Hyslop 1984). Por esta razón, uno de los factores preincaicos determinantes de la ubicación de un camino inca era el patrón de asentamiento regional (Hyslop 1984: 249). Pensamos que en el sector meridional del corredor del Alto Loa, algunos sitios estuvieron funcionalmente vinculados con caseríos locales preexistentes, que se convirtieron en sitios satélites durante el Tawantinsuyu. Probablemente, estas estancias agropastoriles pasaron a ser asentamientos de servicios, consagrados al abastecimiento de los sitios laterales de la arteria y de los campamentos mineros de la Cordillera del Medio. El caso más claro pareciera ser el caserío SBa-518 respecto de Bajada del Toro, pero también podría ser el caso del caserío SBa-41 respecto de Cerro Colorado-1 y de los caseríos SBa-103 y SBa-119 respecto de Santa Bárbara (SBa-109), aunque en este último lugar no hemos podido confirmar una ocupación incaica. Estas conexiones, así como la importante presencia de cerámicas de la región tanto en los sitios laterales como en la propia arteria, llevan a concluir que el involucramiento de la pequeña población local en las operaciones incaicas fue mucho más activo y directo de lo que pudiera pensarse. Por eso nos preguntamos si no será estéril a estas alturas seguir discutiendo si el control inca en la región fue indirecto (Llagostera 1976; Salazar 2002; Uribe y Carrasco 1999) o directo (Núñez 1999; Uribe y Carrasco 1999). En esta etapa de la investigación, pareciera más productivo concentrarse en dilucidar los medios empleados por las autoridades incaicas para obtener la participación de mano de obra local en los proyectos estatales.

6) Los caminos no son simples estructuras físicas que posibilitan el movimiento hacia o desde un determinado destino y tampoco desempeñan funciones puramente militares o económicas; son también poderosos instrumentos simbólicos para la conquista y la dominación (Witcher 1997). Es bien sabido que los caminos incaicos operaban como un símbolo o "bandera" del Estado Inca, por su gran visibilidad y la manera clara en que vinculaban políticamente a los individuos con la autoridad central (Hyslop 1984: 271, 341, citando a Murra 1978 [1955]). En este sentido, pensamos que el alineamiento del sitio Cerro Colorado-1 (SBa-162) con el mítico Cerro Cirahue y con el sitio-tipo del estilo de arte rupestre de Taira y sus manantiales (ver Berenguer 1999), difícilmente es una coincidencia. Intuimos que se trata de un potente enunciado de poder, ideología y simbolismo, mediante el cual los incas se apropiaron y resignificaron un lugar ancestralmente importante dentro del paisaje sagrado de la población del valle (ver discusión en Berenguer 2004b), acaso para asegurarse el concurso de la mano de obra local. De ahí, probablemente, la existencia de una cancha y un ushnu en Cerrro Colorado-1, dos rasgos arquitectónicos de importancia ritual que son clave en la gestión administrativa de los incas y en el manejo que hacían de la fuerza laboral. Postulamos como hipótesis de trabajo que, en su calidad de sitio primario del sector meridional del Alto Loa, Cerro Colorado-1 fue un centro administrativo, donde periódicamente se convocaba a mineros, agricultores y pastores de las inmediaciones, para agasajos ceremoniales organizados por las autoridades con motivo de prestaciones colectivas de trabajo al Estado. Las excavaciones que hemos realizado en este sitio han resultado consistentes con esta interpretación y serán materia de otra publicación.

7) El conocimiento arqueológico se construye sobre la base de evidencia positiva, pero también sobre la base de "evidencia negativa". En efecto, al igual que lo reportado en 12 tramos de caminos por Hyslop (1984) entre Ecuador y Chile (ver también un décimo tercer trayecto en Hyslop y colaboradores 1992), constatamos una total ausencia de arte rupestre en $125 \mathrm{~km}$ de camino inca del Alto Loa. Y eso que ésta es un área excepcionalmente rica en este tipo de manifestaciones (Berenguer 1999). Por lo tanto, al menos desde la perspectiva de nuestros datos, los grabados y pinturas sobre roca no fueron un ingrediente de la vialidad incaica, y la controversia acerca de si en realidad hubo un arte rupestre propiamente incaico en la región (Berenguer 1999, 2004a; Gallardo et al. 1999; Gallardo y Vilches 1995; Núñez 1999; Varela 1999; Vilches y Uribe 1999), debiera excluir al Qhapaqñan de la discusión (Berenguer 2004b). Sobre todo tomando en cuenta nuestro argumento inicial, basado en Hyslop (1984) y Nielsen (1997 Ms), de que el Alto Loa es un área relativamente aislada y desolada, donde la conservación arqueológica es excelente y los componentes incaicos -incluyendo un supuesto arte rupestre inca- debieran ser más evidentes que en zonas más densamente pobladas, debido a que las influencias culturales locales son mínimas. 
8) También es necesario referirse al significado de las conexiones del camino inca del Alto Loa con Lasana. La desviación del camino que se produce al sur de la "puerta" RP-17 y continúa en los puntos RP-25, 26, 27, 28 y 30, desciende por la cuesta RP-29 e irrumpe en la quebrada del Loa justo frente al Pucara de Lasana. Pese a que Rydén (1944) excluye al río Loa de la esfera de influencia de los incas, en su descripción de este pucara admite que, tanto los muros hastiales como las ventanillas en forma de cruz de una de las estructuras pueden ser elementos arquitectónicos incaicos. El sitio es hoy día un monumento nacional y no está permitido excavarlo, pero análisis de cerámica de superficie indican una ocupación entre los siglos XIII y XVI, que incluye momentos posteriores al contacto entre indígenas y españoles (Ayala y Uribe 1994; Berenguer 2004a). En otras palabras, si bien la cerámica propiamente inca encontrada en la localidad es escasa (Pollard 1970: 302), el pucara efectivamente estuvo ocupado durante el dominio incaico de la región. Una parte importante de la producción de alimentos y de otros enseres en Lasana tiene que haber sido canalizada por los incas hacia los campamentos mineros cercanos, incluyendo Conchi Viejo y El Abra. El flujo de suministros hacia estos dos últimos puntos debe haberse efectuado a través de la mencionada desviación, para retomar el troncal del Alto Loa hacia el norte. Con esta hipótesis en mente, sería conveniente en el futuro revaluar la cronología y funcionalidad del sitio de muros y cajas RanL-348A, situado al frente de la cuesta RP-29, así como de los 10 a 15 "refugios de plataforma" del sitio RanL-344 (Pollard 1970), a través de los cuales pasa dicha cuesta. Podrían ser manifestaciones locales del ceremonialismo y del caravaneo por el Qhapaqñan durante el Tawantinsuyu. Asimismo, sería conveniente dilucidar más adelante si el "único caso de tumbas preparadas con adobes estructurados" (son al menos 100 cámaras rectangulares subterráneas con paredes de piedras de lajas, Rydén 1944), del espacialmente segregado cementerio Los Antiguos (RanL-347) de Lasana, "es poco frecuente en la región": a) porque allí se enterró una población intrusiva de origen altiplánico (Núñez y Dillehay 1979); b) porque allí se inhumaron individuos pertenecientes a la élite local (Berenguer 2004a); o c) porque allí se colocaron los restos de los más altos estamentos de funcionarios incaicos del Alto Loa.
9) Resta por último discutir críticamente la idea mencionada al comienzo del artículo de que el camino del Alto Loa fue el trayecto local del "camino costero", "camino de los llanos" o "camino real de la costa". Es cierto: a) que su proyección más lógica hacia el norte debiera empalmar con los segmentos de este camino identificados por Santoro (1982) y, quizás, con los reportados por Núñez (1965) en la Región de Tarapacá y hacia el sur, con los segmentos de este camino prospectados por Hyslop (1984), Iribarren y Bergholz (1971) y Niemeyer y Rivera (1983) en el "Despoblado de Atacama", que parecen corresponder al eje longitudinal que pasa por el norte de Chile; b) que hasta ahora no existe ningún antecedente publicado de un camino inca longitudinal al oeste de la Cordillera del Medio, es decir, que pase por la Pampa del Tamarugal y el desierto central; c) que desde la perspectiva de los recursos hídricos, el Alto Loa se halla muchísimo mejor dotado que sectores situados en latitudes equivalentes del Desierto de Atacama, lo que no es un dato irrelevante en términos de logística del tráfico; y d) que el patrón de hallazgo de cerámica inca o imperial en el camino del Alto Loa se ajusta al encontrado por Hyslop (1984) y Niemeyer y Rivera (1983) en el camino del "Despoblado" (ver Uribe y Cabello $2004 \mathrm{Ms}$ ) y difiere del reportado hasta la fecha en el camino del Alto Salado (Varela 1999). ${ }^{12}$ Todo esto es rigurosamente cierto, sin embargo, todavía no podemos descartar que un troncal incaico -aún no encontradohaya discurrido por el desierto central. Localizar este presunto troncal escapa a los objetivos de nuestra investigación, pero es una tarea que se debieran afrontar en el futuro.

Por otra parte, no puede pasarse por alto que en Ujina, Le Paige (1958) reporta una bifurcación del camino inca, con una arteria que se dirige al

12 Es más, en los sitios MI-1 (Tramo 1, Miño-Esquina) y SBa162 (Tramo 7, Cerro Colorado-Santa Bárbara) existen los porcentajes de cerámica Inka Cusco Policromo (INK) más altos de la región ( $12 \%$ y $9 \%$, respectivamente). Sería tentador (y probablemente acertado) sugerir que el consistente hallazgo de cerámica de esta índole en el Alto Loa y en el "Despoblado", y su baja representatividad en otras zonas, obedece a que en los primeros dos casos se trata de caminos "principales" y en el segundo, de caminos "secundarios". Sin embargo, compartimos por ahora la cautela expresada por Martin (2004 Ms) en otro contexto, en el sentido de no jerarquizar prematuramente caminos cuya funcionalidad todavía desconocemos. 
sur por el Alto Loa y otra que lo hace más al este, por los salares de Carcote o San Martín y Ascotán, presentando al sur nuevas bifurcaciones. En efecto, aparte de una referencia muy general e indirecta de Mostny (1949: 180) en cercanía al Cerro Pabellón del Inca (cerca de Collaguasi), prácticamente todo lo que se tiene en la literatura publicada es la aseveración de Le Paige (1958: 79-80) en el sentido de que el camino inca viene del norte por el altiplano tarapaqueño y que en Ujina se divide en un brazo que desciende por el Alto Loa y otro que lo hace por los salares de Carcote y Ascotán. Más específico es el derrotero que hipotetiza Raffino (1981) entre Sibaya y Turi. Sobre la base de antecedentes bibliográficos (arqueológicos y documentales), el autor une sitios mixtos (incas y locales), sitios puros (incas sin contacto local) y sitios incas referidos etnohistóricamente, para postular el siguiente recorrido: Sibaya-Sacaya-El Tojo- Huayco-Pabellón del Inca-Miño-Cebollar-Ascotán-Cupo-Turi. Con todo, el autor no se hace cargo de la bifurcación en Ujina, indicada por Le Paige, fundiendo, al parecer, las dos vías en una sola. En otras palabras, los incas pueden haber tenido no uno, sino tres o más caminos longitudinales de acceso por el norte al territorio atacameño (además, por supuesto de varios caminos transversales o diagonales). De ahí que la noción de un único "camino longitudinal de la costa" aparezca, al menos por el momento, más como una mistificación derivada de las fuentes documentales, que como una realidad. Para usar términos de navegación electrónica: el Qhapaqñan en la Región de Antofagasta y eventualmente en muchas otras partes, pareciera organizarse o articularse de manera "hipertextual", con "links" para múltiples lados. A medida que los trabajos en terreno vayan levantando información específica y tangible sobre la traza y el derrotero de la red vial incaica, prevemos que las bifurcaciones, variantes y enlaces serán más la regla que la excepción, conformando una red mucho más redundante de lo que supusieron previas investigaciones del Qhapaqñan $y$, por cierto, de lo que plantea la incipiente teoría general en arqueología sobre caminería en sociedades complejas (p.e., Earle 1991; Trombold 1991; Witcher 1997). Consideraciones de variación estacional en las condiciones de tránsito por algunas zonas, de flujo más directo y expedito de la información, de rápida movilización de tropas, de conectividad con focos productivos importan- tes no necesariamente alineados con uno $\mathrm{u}$ otro eje vial y, quizás, de diversas fases de la ocupación cuzqueña del espacio regional, entre varias otras, pueden explicar esta "hipertextualidad" de la red.

Digamos para finalizar que, mirados los resultados de nuestra investigación desde una perspectiva "panandina" (sensu Hyslop 1984: 337), aportamos argumentos factuales y conceptuales a la tarea de ampliar, revisar y confirmar conclusiones y observaciones de otras investigaciones en los Andes acerca de la unidad y la diversidad del Qhapaqñan. Mirados desde una perspectiva regional, en cambio, utilizamos los datos de la investigación para iluminar algunos aspectos que son de vital importancia para evaluar el complejo y aún no bien entendido proceso histórico de la Región de Antofagasta en tiempos del Tawantinsuyu. Dado que los caminos constituyen evidencias tangibles de vínculos culturales, económicos y sociopolíticos a través del espacio (Trombold 1991), la investigación arqueológica de la red vial de los incas en el Alto Loa ofrece una oportunidad poco común para abordar estos aspectos en la región. Estamos ciertos que este género de investigación contribuirá no sólo a sentar las bases para una primera síntesis regional sobre el trazado de esta red en tierras atacameñas, sino también a perfilar mejor el proceso de construcción del espacio provincial por los incas en la antigua Atacama.

Reconocimientos Agradecemos a Mauricio Uribe y Gloria Cabello por los análisis de cerámica encontrada a lo largo del camino, y a esta última y a nuestro memorista Carlos González por su participación en la prospección de varios tramos del camino. La Dirección de Obras Hidráulicas de Calama facilitó alojamiento para el equipo en el embalse de Conchi y la Empresa de Servicios Sanitarios de Antofagasta hizo lo mismo en la Captación Lequena. Estamos también muy agradecidos de Luisa Huánuco y familia, quienes continuamente nos facilitan dependencias de su estancia para guardar nuestros equipos de campo. Nos sentimos igualmente en deuda con Juan Galleguillos, Nicolás Aimani y Marino Gabriel, quienes compartieron generosamente con nosotros sus conocimientos sobre el área de estudio. Además, Marino y su esposa, Juana Chayapa, nos acogieron cálidamente en su estancia de Chela con motivo de nuestras expediciones. 


\section{REFERENCIAS CITADAS}

AYALA, P. y M. URIBE, 1994. Pucara de Lasana: Revalidación de un sitio "olvidado" a partir de un análisis cerámico de superficie. Hombre y Desierto 9, T II: 135-141.

BERENGUER, J., 1994. Recientes hallazgos de evidencias incaicas en el Sector Santa Bárbara, Alto Loa. Boletín de la Sociedad Chilena de Arqueología 18: 10-16.

-1999. El evanescente lenguaje del arte rupestre en los Andes atacameños / The vanishing language of rock art in the Andes of Atacama. En Arte rupestre en los Andes de Capricornio / Rock art in the Andes of Capricorn, J. Berenguer y F. Gallardo (Eds.), pp. 9-56. Museo Chileno de Arte Precolombino / Banco Santiago, Santiago.

-2004a. Tráfico de caravanas, interacción y cambio en el Desierto de Atacama. Sirawi Ediciones, Santiago.

2004b. Cinco milenios de arte rupestre en los Andes atacameños: Imágenes para lo humano, imágenes para lo divino. Boletín del Museo Chileno de Arte Precolombino 9: $75-108$.

BERENGUER, J. y A. NIELSEN, 2003 Ms. Proyecto FONDECYT 7010327 de Incentivo a la Cooperación Internacional, Informe de Avance, Anexo 10.

BOLETIN DE LA GUERRA DEL PACIFICO 1879-1881, 1979. Editorial Andrés Bello, Santiago.

CAJIAS, F., 1975. La Provincia de Atacama (1825-1842). Instituto Boliviano de Cultura, La Paz.

CAÑETE y DOMINGUEZ, J. V., 1974 [1797]. Documento $\mathrm{n}^{\circ} 2$ del Partido de Atacama. Norte Grande 1 (2): 243251.

CASTRO, V., 1992. Nuevos registros de la presencia inca en la Provincia de El Loa, Chile. Gaceta Arqueológica Andina VI (21): 139-154.

CASTRO, V. y V. VARELA, 2000. La dimensión ceremonial en los caminos del Inka: Una reflexión desde la etnografía. Actas del XIV Congreso Nacional de Arqueología Chilena, pp. 815-839. Copiapó.

CONSECOL, 1988. Diagnóstico agrícola, Provincia El Loa, II Región. Tomo I. Consecol Ltda., Santiago.

CORNEJO, L., 1995. El Inka en la Región del río Loa: Lo local y lo foráneo. Actas del XIII Congreso Nacional de Arqueología Chilena, pp. 203-212. Antofagasta.

DERRUAU, M., 1966. Geomorfología. Ediciones Ariel, Barcelona.

EARLE, T., 1991. Paths and roads in evolutionary perspective. En Ancient road networks and settlement hierarchies in the New World, C. D. Trombold (Ed.), pp. 10-16. Cambridge University Press, Cambridge.
ESSAN, 1992. Plan de desarrollo para los servicios de agua potable y alcantarillado de ESSAN S.A.: Definición del Proyecto de Inversión. Anexos al Tomo II, vol. A. Empresa de Servicios Sanitarios de Antofagasta S.A., Santiago.

GALLARDO, F. y F. VILCHES, 1995. Nota acerca de los estilos de arte rupestre en el Pucara de Turi (norte de Chile). Boletín de la Sociedad Chilena de Arqueología 20: 26-28.

GALLARDO, F., C. SINCLAIRE y C. SILVA, 1999. Arte rupestre, emplazamiento y paisaje en la precordillera del Desierto de Atacama. En Arte rupestre en los Andes de Capricornio, J. Berenguer y F. Gallardo (Eds.), pp. 5796. Museo Chileno de Arte Precolombino / Banco Santiago, Santiago.

GARCILASO DE LA VEGA, I., 1995 [1604]. Comentarios reales de los Incas. Fondo de Cultura Económica, México D. F.

GUAMAN POMA DE AYALA, F., 1980 [1616?]. El primer nueva corónica y buen gobierno, J. Murra y R. Adorno (Eds.). Siglo Veintiuno Editores, México, D. F.

HYSLOP, J., 1984. The Inca road system. Academic Press, Orlando.

- 1991. Observations about research on prehistoric roads in South America. En Ancient road networks and settlement hierarchies in the New World, C. D. Trombold (Ed.), pp. 28-33. Cambridge University Press, Cambridge.

1992. Qhapaqñan. El sistema vial incaico. Instituto Andino de Estudios Arqueológicos, Lima.

HYSLOP, J. y M. RIVERA, 1984. An expedition on the Inca road in the Atacama Desert. Archaeology 37 (6): 33-39.

HYSLOP, J., B. GUERRERO y L. E. LUMBRERAS, 1992. El camino inca entre el río Yanahuanca (Chaupi Waranga) y la ciudad inca de Huánuco Pampa, Departamentos de Pasco y Huánuco, Perú. Gaceta Arqueológica Andina VI (21): 55-79.

IGM, 1990. Geografía II Región de Antofagasta. Colección Geografía de Chile. Instituto Geográfico Militar, Santiago.

IRIBARREN, J. y H. BERGHOLZ, 1972. El camino del Inca en un sector del Norte Chico. Colección 11 de Julio, Salvador.

LATCHAM, R. E., 1928. La alfarería indígena chilena. Sociedad Impresora y Litográfica Universo, Santiago.

1938. Arqueología de la Región Atacameña. Prensas de la Universidad de Chile, Santiago.

LE PAIGE, G., 1958. Antiguas culturas atacameñas en la cordillera chilena. Anales de la Universidad Católica de Valparaíso 4-5. 
LEVILLIER, R., 1942. Don Francisco de Toledo - Supremo Organizador del Perú. Colección de Publicaciones Históricas de la Biblioteca del Congreso Argentino, Buenos Aires.

LLAGOSTERA, A., 1976. Hipótesis sobre la expansión incaica en la vertiente occidental de los Andes meridionales. En Homenaje al Dr. R. P. Gustavo Le Paige, L. Núñez (Ed.), pp. 203-218. Universidad del Norte, Antofagasta.

LYNCH, T. F., 1995-1996. Inca roads in the Atacama: Effects of later use by mounted travellers. Diálogo Andino 14/ 15: 187-203.

LYNCH, T. F. y L. NUÑEZ, 1994. Nuevas evidencias incas entre Kollahuasi y Río Frío (I y II Regiones del norte de Chile). Estudios Atacameños 11: 145-164.

MAGAlLANES, M., 1912. El Camino del Inka. Revista Chilena de Historia y Geografía T III (7).

MARTIN, S., 2004 Ms. Caminos incaicos "principales" y "secundarios" en la sierra de Famatina (La Rioja, Argentina): Actualización y revisión conceptual.

MOSTNY, G., 1949. Ciudades atacameñas. Boletín del Museo Nacional de Historia Natural 24: 125-211.

MURRA, J. V., 1978 [1955]. La organización económica del Estado inca. Siglo Veintiuno, México, D. F.

NIELSEN, A., 1997. El tráfico caravanero visto desde La Jara. Estudios Atacameños 14: 339-371.

_-1997 Ms. Incas en Lípez: Primera aproximación. Trabajo presentado al simposio "El Estado inca: Desde la periferia al epicentro", XII Congreso Nacional de Arqueología Argentina, La Plata.

NIEMEYER, H. y M. RIVERA, 1983. El Camino del Inka en el Despoblado de Atacama. Boletín de Prehistoria de Chile 9: 91-193.

NUÑEZ, L., 1965. Desarrollo cultural prehispánico del norte de Chile. Estudios Arqueológicos 1: 7-115.

-1976. Geoglifos y tráfico de caravanas en el desierto chileno. En Homenaje al Dr. R.P. Gustavo Le Paige, L. Núñez (Ed.), pp. 147-201. Universidad del Norte, Antofagasta.

__ 1999. Valoración minero-metalúrgica circumpuneña: Menas y mineros para el Inka rey. Estudios Atacameños 18: $177-221$.

NUÑEZ, L. y T. DILLEHAY, 1979. Movilidad giratoria, armonía social y desarrollo en los Andes Meridionales: Patrones de tráfico e interacción económica. Universidad del Norte, Antofagasta.

OCHSENIUS, C., 1974-75. Relaciones paleobiogeográficas y paleoecológicas entre los ambientes lénticos de la puna y el altiplano boliviano, Trópico de Capricornio. Boletín de Prehistoria de Chile 7-8: 101-137.
PINO, M., 1998 Ms. Geoarqueología del sector del Alto del río Loa, comprendido entre los sectores Los Encuentros y Milla. Anexo del Segundo Informe de Avance del Proyecto FONDECYT 1960045, Santiago.

POLLARD, G. C., 1970. The cultural ecology of CeramicStage of the Atacama Desert. Ph.D. Dissertation, Columbia University, University Microfilms Int., Ann Arbor.

RAFFINO, R., 1981. Los incas del Collasuyu. Ramos Americana Editora, La Plata.

RAMIREZ, C. y C. HUETE, 1981. Hoja Ollagüe. En Carta geológica de Chile. Instituto de Investigaciones Geológicas, Santiago.

REGAL, A., 1936. Los caminos del Inka en el antiguo Perú. Sanmartí, Lima.

RISOPATRON, L., 1911. La línea de frontera con la República de Bolivia. Sociedad Imprenta y Litografía Universo, Santiago.

_ 1918. Diario de viaje a las cordilleras de Antofagasta y Bolivia (1903-1904). Revista Chilena de Historia y Geografía T XXVII.

— 1924. Diccionario jeográfico de Chile. Imprenta Universitaria, Santiago.

ROMERO, A. y L. BRIONES, 1999. Co-37: Estado y planificación inca en Collahuasi (Provincia de Iquique, I Región, Chile). Estudios Atacameños 18: 141-14.

ROMERO, H. y A. RIVERA, 1985. Geografía de los climas. Geografía de Chile 12.

ROMERO, C., 1978. Caminos de ayer y de hoy. En Tecnología andina, R. Ravinés (Ed.), pp. 627-640. Instituto de Estudios Peruanos, Lima.

RYDEN, S., 1944. Contributions to the archaeology of the Rio Loa Region. Elanders Boktrickery Aktiebolag, Göteborg.

SALAZAR, D., 2002. El Complejo Minero San José del Abra, II Región (1450-1536 DC): Una aproximación a la arqueología de la minería. Tesis para optar al Grado de Magíster en Arqueología, Facultad de Ciencias Sociales, Universidad de Chile, Santiago.

SANHUEZA, C., 1991. Origen y desarrollo de la arriería indígena colonial en Atacama, siglos XVI-XVII. Tesis para optar al grado de Licenciada en Historia, Pontificia Universidad Católica de Chile, Santiago.

2004. "Medir", "amojonar", "repartir": Territorialidades y prácticas demarcatorias en el camino incaico de Atacama (II Región, Chile). Chungara 36 (2): 483-494.

SANTORO, C., 1982. Camino inca en la sierra de Arica. Chungara 10: 47-56.

STRUBE, L., 1963. Vialidad imperial de los incas. Serie Histórica 33. Instituto de Estudios Americanos, Facultad de 
Filosofía y Humanidades, Universidad Nacional de Córdoba, Córdoba.

TROMBOLD, C. D., 1991. An introduction to the study of ancient New World road networks. En Ancient road networks and settlement hierarchies in the New World, C. D. Trombold (Ed.), pp. 1-9. Cambridge University Press, Cambridge.

URIBE, M. y C. CARRASCO, 1999. Tiestos y piedras talladas de Caspana: El espacio mortuorio local durante el Tawantinsuyu. Estudios Atacameños 18: 55-71.

URIBE, M. y G. CABELLO, 2004 Ms. Cerámica en el camino: Implicancias tipológicas y conductuales para la comprensión de la vialidad y la expansión del Tawantinsuyu en el río Loa (Norte Grande de Chile).

VARELA, V., 1999. El Camino del Inka en la cuenca superior del río Loa, Desierto de Atacama, norte de Chile. Estudios Atacameños 18: 89-105.
VILCHES, F. y M. URIBE, 1999. Grabados y pinturas del arte rupestre tardío de Caspana. Estudios Atacameños 18: 73-87.

VITRY, C., 2002. Apachetas y mojones, marcadores espaciales del paisaje prehispánico. Revista Escuela de Historia 1 (1): 179-191.

VON HAGEN, V. W., 1955. Highway of the Sun. Duell, Sloan and Pearce, Nueva York.

WHITTOW, J. B., 1988. Diccionario de geografía física. Alianza Editorial S. A., Madrid.

WITCHER, R., 1997. Roman roads: Phenomenological perspectives on roads in the landscape. En Proceedings of the Seventh Annual Theoretical Roman Archaeology Conference, C. Forcey, J. Hawthorne y R. Witcher (Eds.), pp. 60-70. Oxbow, Oxford. 
